\title{
Percutaneous coronary invervention versus coronary artery bypass grafting: A meta-analysis
}

\author{
Yolba Smit, MD, MSc, ${ }^{\mathrm{a}}$ Joan Vlayen, MD, ${ }^{\mathrm{b}}$ Hetty Koppenaal, MD, MPH, ${ }^{\mathrm{c}}$ Frank Eefting, MD, ${ }^{\mathrm{d}}$ \\ Arie Pieter Kappetein, $\mathrm{MD}, \mathrm{PhD},{ }^{\mathrm{e}}$ and Massimo A. Mariani, $\mathrm{MD}, \mathrm{PhD}^{\mathrm{f}}$
}

\section{ABSTRACT}

Objective: To compare the effectiveness of percutaneous coronary intervention (PCI) and coronary artery bypass grafting $(\mathrm{CABG})$ in patients with coronary artery disease.

Methods: MEDLINE, Embase, and Cochrane Central were searched, and randomized controlled trials were included. Outcomes were assessed at maximum available follow-up.

Results: This meta-analysis includes 31 trials with 15,004 patients. As regards death, more patients died after PCI compared with CABG across all types of patients (odds ratio [OR], $1.1 ; 95 \%$ confidence interval $[\mathrm{CI}], 1.0-1.3 ; P=.05$ ) as well as in patients with multivessel disease (OR, 1.2; 95\% CI, 1.0-1.4; $P=.02$ ) or diabetes (OR, 1.6; 95\% CI, 1.2-2.1; $P<.01$ ). Myocardial infarction occurred as frequently after PCI (OR, 1.2; 95\% CI, 0.9-1.5; $P=.28)$. Repeat revascularization was more common after PCI (OR, 4.5 ; 95\% CI, 3.5-5.8; $P<.01$ ), with a progressive decline in ORs from the pre-stent era (OR, 7.0; 95\% CI, 5.1-9.7; $P<.01$ ), to the bare metal stent era $(\mathrm{OR}, 4.5 ; 95 \% \mathrm{CI}, 3.6-5.5 ; P<.01)$, and to the drugeluting stent era $(\mathrm{OR}, 2.5 ; 95 \% \mathrm{CI}, 1.8-3.4 ; P<.01)$. Stroke was more common after CABG (OR, $0.7 ; 95 \% \mathrm{CI}, 0.5-0.9 ; P=.01)$.

Conclusions: Compared with PCI, CABG had a lower risk of death in multivessel disease or diabetes patients eligible for either intervention, a lower risk of repeat revascularization, but a higher risk of stroke. (J Thorac Cardiovasc Surg $2015 ; 149: 831-8)$

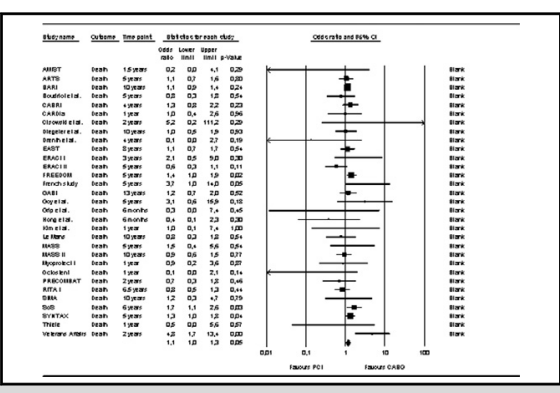

Meta-analysed odds ratio for death after PCl or CABG at the latest available follow-up.

\section{Central Message}

We conducted a meta-analysis comparing the effectivenes of PCI to CABG in 31 trials on 15,004 patients. Compared to $\mathrm{PCI}, \mathrm{CABG}$ had a lower risk of death in patients with multivessel disease or diabetes, and a lower risk of repeat revascularization and a higher risk of stroke in all patients.

\section{Author Perspective}

This paper supports current thoughts in myocardial revascularization directed to reconsider the role of surgical myocar dial revascularization in patients with extensive coronary artery disease, particularly when affected by diabetes. On the other hand, this paper confirms that additional effort should be put in lowering the risk of perioperative neurologic complications in surgical myocardial revascularization because stroke is a rare but devastating and invalidating complication. Off-pump and aortic "no-touch" techniques may play a role in this perspective.

See Editorial Commentary pages 839-40.

\section{Supplemental material is available online.}

Revascularization for coronary artery disease can be performed with coronary artery bypass grafting (CABG) or percutaneous coronary intervention (PCI). For more than 20 years, trials have compared the effectiveness and safety of PCI versus CABG. The first trials compared balloon angioplasty to CABG. Improved technology has made it possible to treat increasingly complex lesions

\footnotetext{
From Independent Researcher, ${ }^{\mathrm{a}}$ Leuth, The Netherlands; ME-TA, ${ }^{\mathrm{b}}$ Rotselaar, Belgium; Independent Researcher, ${ }^{c}$ Vlissingen, The Netherlands; Department of Cardiology, ${ }^{\mathrm{d}}$ St Antonius Hospital, Nieuwegein, The Netherlands; Department of Cardiothoracic Surgery, ${ }^{\mathrm{e}}$ Erasmus Medisch Centrum, Rotterdam, The Netherlands; and Department of Cardiothoracic Surgery, ${ }^{\mathrm{f}}$ University Medical Centre Groningen, University of Groningen, Groningen, The Netherlands.

This work was supported by the Health Care Insurance Board, Diemen, The Netherlands, and the Department of Cardiothoracic Surgery, University Medical Center Groningen, University of Groningen, Groningen, The Netherlands.
}

with PCI. At the same time, the outcome of CABG has improved because of better perioperative care and extended use of arterial revascularization. After the introduction of bare metal stents, several trials compared PCI with CABG in patients with multivessel disease. More recently, data from randomized trials of drug-eluting stents have shown significant reductions in the rate of repeat interventions with respect to bare metal stents. The latest trials therefore focused on PCI with drug-eluting stents versus CABG.

Earlier meta-analyses of randomized controlled trials (RCTs) comparing PCI versus CABG have been undertaken

\footnotetext{
Received for publication April 23, 2014; revisions received Oct 17, 2014; accepted for publication Oct 25, 2014; available ahead of print Nov 25, 2014

Address for reprints: Massimo A. Mariani, MD, PhD, Department of Cardiothoracic Surgery, University Medical Center Groningen, University of Groningen, P.O. Box 30.001, 9700 RB Groningen, The Netherlands (E-mail: m.mariani@umcg.nl). $0022-5223 / \$ 36.00$

Copyright $(2015$ by The American Association for Thoracic Surgery http://dx.doi.org/10.1016/j.jtcvs.2014.10.112
} 


\begin{tabular}{|c|c|c|c|}
\hline \multirow{2}{*}{\multicolumn{2}{|c|}{ Abbreviations and Acronyms }} & RCT & $=$ randomized controlled trial \\
\hline & & RITA & $=$ Randomised Intervention \\
\hline & Invasive Surgery Trial & SIMA & $\begin{aligned} & \text { Treatment of Angina } \\
= & \text { Stenting versus Internal Mammary }\end{aligned}$ \\
\hline & $\begin{aligned}= & \text { Arterial Revascularization } \\
& \text { Therapies Study }\end{aligned}$ & SYNTAX & Artery grafting trial \\
\hline AWESOME & $\begin{aligned}= & \text { Angina With Extremely Serious } \\
& \text { Operative Mortality Evaluation }\end{aligned}$ & & $\begin{array}{l}\text { Coronary Intervention With Taxus } \\
\text { and Cardiac Surgery }\end{array}$ \\
\hline BARI & $=$ Bypass Angioplasty & & \\
\hline
\end{tabular}

$=$ Coronary Angioplasty versus Bypass Revascularisation Investigation

$\mathrm{CAD}=$ coronary artery disease

CARDia $=$ Coronary Artery

Revascularization in Diabetes

CI $\quad=$ confidence interval

EAST $\quad=$ Emory Angioplasty versus Surgery Trial

EXCEL = Coronary Artery Bypass Surgery for Effectiveness of Left Main Revascularization

ERACI I $=$ Argentine Randomized Trial of Percutaneous Transluminal Coronary Angioplasty Versus Coronary Artery Bypass Surgery in Multivessel Disease

ERACI II = Argentine Randomized Trial of Coronary Angioplasty With Stenting Versus Coronary Bypass Surgery in Patients with Multiple Vessel Disease trial

FREEDOM = Future REvascularization Evaluation in patients with Diabetes mellitus: Optimal management of Multivessel disease

GABI = German Angioplasty Bypass Surgery Investigation

LAD = left anterior descending coronary artery

LMCA = left main coronary artery

MASS = Medicine, Angioplasty, or Surgery Study

OR $=$ odds ratio

PCI $=$ percutaneous coronary intervention

PRECOMBAT $=$ Premier of Randomized Comparison of Bypass Surgery versus Angioplasty Using Sirolimus-Eluting Stent in Patients with Left Main Coronary Artery Disease with the purpose of evaluating both treatment modalities. These meta-analyses either are now outdated ${ }^{\mathrm{E} 1-\mathrm{E} 3}$ or present only part of the picture, as they looked at particular disease categories, ${ }^{\text {E4-E10 }}$ specific types of surgery or $\mathrm{PCI},{ }^{\mathrm{E} 1, \mathrm{E} 7, \mathrm{E} 11}$ or specific patients. ${ }^{\mathrm{E} 12}$ Individual patient data meta-analyses have the advantage that time-to-event curves can be produced, and analyses of effects in clinically important subgroups can be estimated. However, they are limited by the willingness and/or ability of research groups to participate and share data. ${ }^{\text {E13-E15 }}$

The present meta-analysis aims to compare the effectiveness and safety of PCI and CABG in patients for whom coronary revascularization is clinically indicated.

\section{METHODS}

\section{Search Strategies}

We used Cochrane systematic review methods to identify RCTs that met the inclusion criteria. MEDLINE, Embase, and Cochrane Central were searched on December 18, 2013, using text words and medical subheadings. Searches were limited to studies published from 1996 onwards, published in English, and undertaken in humans. Because of continuous improvement of techniques, devices, and medical treatment, studies published before 1996 were considered too old to have policy implications for current clinical practice. References of meta-analyses, reviews, and selected articles were scanned for additional RCTs. The websites www.controlled-trials.com and clinicaltrial.gov were searched for running and unpublished trials, and when such trials were found, the Internet was searched for preliminary or early results. Two databases (Database of Abstracts of Reviews of Effects and the Health Technology Assessment database) were searched via http://www.crd.york.ac.uk/crdweb/.

\section{Inclusion Criteria}

Studies were included if they concerned an RCT comparing PCI (with or without stenting) to $\mathrm{CABG}$ and if the trial participants were adults with stable or unstable angina, and had single-vessel or multivessel coronary disease.

\section{Study Selection and Quality Criteria}

Two reviewers (YS and HK or JV) independently selected the studies; discrepancies were resolved by consensus. Selected trials were assessed for their methodological quality (adequacy of randomization, adequacy of the allocation concealment, the potential for selection bias after allocation and the adequacy of masking) by 2 reviewers (YS and HK or JV) using a scheme based on Schulz et al, which was used in Cochrane reviews on CABG and PCI. ${ }^{\mathrm{E} 1, \mathrm{E} 16, \mathrm{E} 17}$

Data were extracted by one reviewer (YS) and checked by a second (HK or JV). Events of interest included the primary outcome measures (all-cause death, myocardial infarction, repeat revascularization, and stroke), secondary outcome measures (cardiac death and angina-free survival), general characteristics of the included studies, and data on study participants (eg, type of

\section{Data Extraction}


vessel involvement). For outcomes, the numerator was the number of events reported; the denominator was the number of patients assigned to a treatment arm (intention-to-treat principle). For myocardial infarction, the number of nonfatal infarctions was taken and, when not available, the number of nonfatal Q-wave infarctions, myocardial infarctions, or myocardial Q-wave infarctions was taken (in that order). For repeat revascularization, the number of procedures was taken and, when not available, the number of patients with a repeat revascularization was taken. When the number of repeat revascularizations was not available, the number of repeat target vessel revascularizations was taken. For angina-free survival, either the number of patients reported to be angina-free was taken or the number of patients with angina was subtracted from the total number of patients minus the dead. For stroke, the number of patients with a nonfatal stroke at follow-up was taken. If not available, the number of patients with a stroke was taken. Data were extracted separately for all reported time points of follow-up (eg, at 1,2, and 5 years of follow-up), and for the clinical significant subgroup of patients with diabetes.

\section{Data Analysis}

Medians were calculated as the middle number in a list of ordered numbers, as a summary statistic for the proportion of screened patients (patients assessed for eligibility) that were included in trials, the proportion of patients lost to follow-up, and the proportion of off-pump CABG in trials that used a mix of on-pump and off-pump techniques. Meta-analyzed outcomes were assessed at maximum available follow-up, unless otherwise specified. Outcomes were presented as odds ratios (ORs) with the corresponding $95 \%$ confidence intervals (CIs). A $P$ value of .05 or smaller was considered statistically significant. A continuity correction of 0.5 was applied in case of zero events in 1 treatment arm. Meta-analyzed results were described using a random effects model. Heterogeneity was assessed with the $\chi^{2} \mathrm{Q}$ statistic, and the $\mathrm{I}^{2}$ metric with its $95 \%$ CIs. ${ }^{\mathrm{E} 18}$ Values of $\mathrm{I}^{2}$ $\geq 75 \%$ suggest very large heterogeneity beyond chance, in which case meta-regression (method of moments) was applied to explore reasons for heterogeneity. Outcomes were also meta-analyzed according to the type of PCI that was evaluated: the pre-stent era (no stents used in the majority of patients, up to 1993); the bare metal stent era (bare metal stents used in the majority of patients, 1994-2001); and the drug-eluting stent era (drug-eluting stents used in the majority of patients, from 2002 onwards). We performed sensitivity analyses excluding studies in which a substantial minority $(10 \%$ or more) of patients received a different type of PCI, for example, in a trial in the bare metal stent era $90 \%$ of patients were treated with bare metal stents and $10 \%$ of patients were treated with drug-eluting stents. Although CABG has evolved as well across these time periodswith a greater use of arterial conduits, off-pump surgery, and minimally invasive surgical techniques-this evolvement is not captured as unequivocal in different eras. In addition, meta-analysis of outcomes at time periods of 6 months, 1 year, 1.5 to 2 years, 2.5 to 3 years, 4 years, and 5 years of follow-up was performed for the primary outcomes. Meta-analyses of primary outcomes were performed separately for trials reporting on different types of vessel disease and for trials using either off-pump or on-pump CABG exclusively. For the subgroup analyses of off-pump versus on-pump CABG, we excluded trials from the pre-stent era, as none of these trials used off-pump CABG. In addition, we performed meta-analyses of primary outcomes for diabetes patients (either trials that exclusively included patients with diabetes or trials that reported on subgroups of patients with diabetes). Funnel plots were constructed and the Duval and Tweedie's trim and fill test was applied to examine publication bias. We undertook sensitivity analyses of subgroups with different quality assessment scores. Analyses were performed using Comprehensive Meta-Analysis software, version 2.0 (Biostat, Englewood, NJ). Stata, version 10.0 (StataCorp, College Station, Tex) was used to calculate $95 \%$ CI for frequencies not provided in original publications and the $95 \%$ CI of I ${ }^{2}$ E19 Microsoft Office Excel 2007 was used for graphs picturing meta-analyzed ORs per time period of follow-up. The ORs given are always for PCI versus CABG.

\section{Role of the Funding Source}

The sponsor of the study had no role in study design, data collection, data analysis, data interpretation, or writing of the report.

\section{RESULTS}

A total of 4837 records were screened out of which 302 articles were selected for full text review. From these 302 articles, 31 RCTs were selected for inclusion, and data from 91 articles pertaining to these trials were used in the meta-analyses. ${ }^{\mathrm{E} 0-\mathrm{E} 110}$ If multiple articles were available on a single study, we would only use the most recent or most comprehensive article, unless data for different time periods of follow-up or for different subgroups of patients were not reported in these articles. A flow diagram in Appendix E1 shows the search and selection process. The Angina With Extremely Serious Operative Mortality Evaluation (AWESOME) trial was excluded because patients with medically refractory unstable ischemia and a high risk of adverse outcomes were involved, ${ }^{\mathrm{E} 11-\mathrm{E} 117}$ whereas the 31 selected RCTs had strict exclusion criteria for patients with a recent myocardial infarction, a previous PCI or CABG, low left ventricular ejection fraction, or serious comorbidity.

\section{Characteristics}

The 31 RCTs included a total of 15,004 randomized patients (Table 1). One more trial of drug-eluting stents versus $\mathrm{CABG}$ is running at present, the Coronary Artery Bypass Surgery for Effectiveness of Left Main Revascularization (EXCEL) trial, but its results have not been published to date. ${ }^{\mathrm{E} 118}$ Nine trials (5200 patients) were conducted in the pre-stent era, 14 trials (4276 patients) in the bare metal stent era, and 8 trials (5528 patients) in the drug-eluting stent era. Mixed PCI treatments did not occur in the pre-stent era. However, in 5 out of 14 trials conducted in the bare metal stent era, more than $10 \%$ of patients randomized to $\mathrm{PCI}$ were treated with either angioplasty alone $(13 \%$ of patients randomized to PCI in the Arterial Revascularization Therapies Study [ARTS] trial, 30\% in the Argentine Randomized Trial of Coronary Angioplasty With Stenting Versus Coronary Bypass Surgery in Patients with Multiple Vessel Disease [ERACI II] trial, $28 \%$ in the Medicine, Angioplasty, or Surgery Study [MASS] II trial, and 22\% in the Stent or Surgery $[\mathrm{SoS}]$ trial) or with drug-eluting stents $(35 \%$ of patients randomized to PCI in the le Mans trial). In the Coronary Artery Revascularization in Diabetes (CARDia) trial, $31 \%$ of patients randomized to PCI were treated with bare metal stents and $69 \%$ with drug-eluting stents (this trial was categorized in the drug-eluting stent era). PCI and CABG were compared in patients with multivessel disease $(\mathrm{n}=12)$, proximal left anterior descending coronary artery (LAD) stenosis $(\mathrm{n}=11)$, patients with main stem stenosis $(\mathrm{n}=4)$, a combination of patients with single- or multivessel disease $(\mathrm{n}=2)$, or 3-vessel or left main coronary artery stenosis $(n=2)$. Trials included a median of $7.8 \%$ of screened patients (range, $2.0 \%-61 \%$ ). Follow-up was available from 
TABLE 1. Characteristics of 31 PCI versus CABG trials, per treatment era

\begin{tabular}{|c|c|c|c|c|c|c|c|c|c|}
\hline $\begin{array}{c}\text { Trial name } \\
\text { (references used) }\end{array}$ & Trial characteristics & $\begin{array}{c}\text { Enrolment } \\
\text { period }\end{array}$ & $\begin{array}{c}\text { Number } \\
\text { of } \\
\text { patients } \\
\text { included }\end{array}$ & $\begin{array}{c}\% \text { Of } \\
\text { screened } \\
\text { patients } \\
\text { enrolled }\end{array}$ & $\begin{array}{c}\text { \% Loss } \\
\text { to } \\
\text { follow-up } \\
\end{array}$ & $\begin{array}{c}\text { Latest } \\
\text { follow-up } \\
\text { available } \\
(y)\end{array}$ & $\begin{array}{c}\text { Main patient } \\
\text { characteristic }\end{array}$ & $\begin{array}{c}\% \text { Off- } \\
\text { pump } \\
\text { CABG }\end{array}$ & $\begin{array}{l}\text { Data on } \\
\text { diabetes } \\
\text { patients }\end{array}$ \\
\hline Pre-stent era & & & 5200 & & & & & & \\
\hline $\mathrm{BARI}^{\mathrm{E} 20-\mathrm{E} 28}$ & $\begin{array}{l}\text { Multicenter, United States } \\
\text { and Canada }\end{array}$ & 1988-1991 & 1829 & 7.3 & 2.8 & 10 & Multivessel CAD & 0 & Yes \\
\hline $\mathrm{CABRI}^{\mathrm{E} 29-\mathrm{E} 32}$ & Multicenter, Europe & 1988-1992 & 1054 & na & 0.4 & 4 & Multivessel CAD & $0 \dagger$ & Yes \\
\hline $\mathrm{EAST}^{\mathrm{E} 33-\mathrm{E} 36}$ & Single-center, United States & $1987-1990$ & 392 & 7.7 & 0 & 8 & Multivessel CAD & 0 & Yes \\
\hline ERACI I ${ }^{\mathrm{E} 37, \mathrm{E} 38}$ & Single-center, Argentina & 1988-1990 & 127 & 17.0 & 1.6 & 3 & Multivessel CAD & 0 & No \\
\hline $\begin{array}{l}\text { French Monocentric } \\
\text { Study }{ }^{\mathrm{E} 39}\end{array}$ & Single-center, France & $1989-1993$ & 152 & 7.8 & na & 5 & Multivessel CAD & 0 & No \\
\hline $\mathrm{GABI}^{\mathrm{E} 40, \mathrm{E} 41}$ & Multicenter, Germany & 1986-1991 & 359 & 4.0 & 0.5 & 13 & Multivessel CAD & 0 & No \\
\hline Goy et $\mathrm{al}^{\mathrm{E} 42, \mathrm{E} 43} \ddagger$ & Single-center, Switzerland & $1989-1993$ & 134 & 2.6 & na & 5 & Proximal LAD stenosis & 0 & No \\
\hline MASS I ${ }^{\mathrm{E} 44, \mathrm{E} 45}$ & Single-center, Brazil & 1988-1991 & 142 & na & na & 5 & Proximal LAD stenosis & 0 & No \\
\hline RITA I $^{\mathrm{E} 46-\mathrm{E} 50}$ & Multicenter, United Kingdom & 1988-1991 & 1011 & 4.4 & 0 & 6.5 & $\begin{array}{l}\text { Single- or multivessel } \\
\text { CAD }\end{array}$ & $0 \dagger$ & Yes \\
\hline Bare metal stent era & & & 4276 & & & & & & \\
\hline $\mathrm{AMIST}^{\mathrm{E} 51} \S$ & Multicenter, United Kingdom & 1999-2001 & 100 & 9.2 & 8.0 & 1.5 & Proximal LAD stenosis & 100 & No \\
\hline ARTS $^{\mathrm{E} 52-\mathrm{E} 59} \|$ & Multicenter, international & 1997-1998 & 1205 & na & 1.7 & 5 & Multivessel CAD & 0 & Yes \\
\hline Cisowski et $\mathrm{al}^{\mathrm{E} 60, \mathrm{E} 61}$ & Single-center, Poland & 2000-2001 & 100 & na & 0 & 2 & Proximal LAD stenosis & 100 & No \\
\hline Diegeler et $\mathrm{al}^{\mathrm{E} 62-\mathrm{E} 64}$ & Single-center, Germany & $1997-2001$ & 220 & na & 3.6 & 10 & Proximal LAD stenosis & 100 & No \\
\hline Drenth et al ${ }^{\mathrm{E} 65-\mathrm{E} 68}$ & Single-center, The Netherlands & 1997-1999 & 102 & na & 0 & 4 & Proximal LAD stenosis & 100 & No \\
\hline ERACI II ${ }^{\mathrm{E} 69, \mathrm{E} 70} \boldsymbol{q}$ & Multicenter, Argentina & 1996-1998 & 450 & 16.3 & 0 & 5 & Multivessel CAD & $0 \dagger$ & Yes \\
\hline Grip et $\mathrm{al}^{\mathrm{E} 71}$ & Single-center, Sweden & 2001 & 53 & na & 0 & 0.5 & Proximal LAD stenosis & 100 & No \\
\hline Kim et $\mathrm{al}^{\mathrm{E} 72}$ & Single-center, South Korea & $2000-2001$ & 100 & na & na & 1 & Proximal LAD stenosis & 100 & No \\
\hline Le Mans ${ }^{\mathrm{E} 73, \mathrm{E} 74} \#$ & Multicenter, Poland & 2001-2004 & 105 & 30.3 & 0 & 10 & Main stem stenosis & 0 & No \\
\hline MASS II ${ }^{\mathrm{E} 75-\mathrm{E} 80 * *}$ & Single-center, Brazil & $1995-2000$ & 408 & 2.0 & 0 & 10 & Multivessel CAD & 0 & Yes \\
\hline Myoprotect ${ }^{\mathrm{E} 81}$ & Single-center, Germany & $1998-2001$ & 44 & na & na & 1 & Main stem stenosis $\dagger \dagger$ & 19 & No \\
\hline Octostent ${ }^{\mathrm{E} 82-\mathrm{E} 84}$ & Multicenter, The Netherlands & $1998-2000$ & 280 & na & na & 7.5 & $\begin{array}{l}\text { Single- or multivessel } \\
\text { CAD }\end{array}$ & 100 & No \\
\hline SIMA $^{\mathrm{E} 85, \mathrm{E} 86}$ & Multicenter, Europe & 1994-1998 & 121 & na & 0 & 10 & Proximal LAD stenosis & 10 & No \\
\hline $\operatorname{SoS}^{\mathrm{E} 87-\mathrm{E} 90}+\neq$ & $\begin{array}{l}\text { Multicenter, Canada and } \\
\text { Europe }\end{array}$ & 1996-1999 & 988 & na & 0.8 & 6 & Multivessel CAD & 3 & Yes \\
\hline Drug-eluting stent era & & & 5528 & & & & & & \\
\hline Boudriot et al ${ }^{\mathrm{E} 91, \mathrm{E} 92}$ & Multicenter, Germany & 2003-2009 & 201 & 46.7 & 0.5 & 5 & Main stem stenosis & 46 & No \\
\hline CARDia ${ }^{\mathrm{E} 93} \S \S$ & $\begin{array}{l}\text { Multicenter, United Kingdom } \\
\text { and Ireland }\end{array}$ & $2002-2007$ & 510 & na & 3.9 & 1 & $\begin{array}{r}\text { Diabetes patients with } \\
\text { multivessel CAD }\end{array}$ & 31 & Yes \\
\hline FREEDOM $^{\text {E94-E96 }}$ & Multicenter, international & $2005-2010$ & 1900 & 5.8 & \pm 1 & 5 & $\begin{array}{r}\text { Diabetes patients with } \\
\text { multivessel CAD }\end{array}$ & 18.5 & Yes \\
\hline Hong et al ${ }^{\mathrm{E} 97}$ & Single-center, South Korea & 2003 & 189 & na & 0.8 & 0.5 & Proximal LAD stenosis & 100 & No \\
\hline PRECOMBAT $^{\text {E98 }}$ & Multicenter, South Korea & 2004-2009 & 600 & 41.3 & 0 & 2 & Main stem stenosis & 64 & No \\
\hline SYNTAX $^{\text {E99-E108 }}$ & Multicenter, international & $2005-2007$ & 1800 & 41.5 & 0.7 & 5 & $\begin{array}{l}\text { 3-vessel or LMCA } \\
\text { stenosis }\end{array}$ & 15 & Yes \\
\hline Thiele et $\mathrm{al}^{\mathrm{E} 109}\|\|$ & Single-center, Germany & 2003-2007 & 130 & 61.0 & 0 & 1 & Proximal LAD stenosis & 100 & No \\
\hline Veterans Affairs ${ }^{\mathrm{E} 110}$ & Multicenter, United States & 2006-2010 & 198 & 3 & na & 2 & $\begin{array}{l}\text { Diabetes patients with } \\
\text { severe CAD } \| \text { ब }\end{array}$ & na & Yes \\
\hline
\end{tabular}

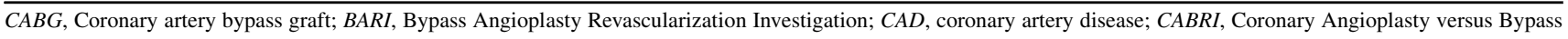
Revascularisation Investigation; na, not available; EAST, Emory Angioplasty versus Surgery Trial; ERACI I, Argentine Randomized Trial of Percutaneous Transluminal Coronary Angioplasty Versus Coronary Artery Bypass Surgery in Multivessel Disease; GABI, German Angioplasty Bypass Surgery Investigation; LAD, left anterior descending coronary artery; MASS, Medicine, Angioplasty, or Surgery Study; RITA, Randomised Intervention Treatment of Angina; AMIST, Angioplasty versus Minimally Invasive Surgery Trial; ARTS, Arterial Revascularization Therapies Study; ERACI II, Argentine Randomized Trial of Coronary Angioplasty With Stenting Versus Coronary Bypass Surgery in Patients with Multiple Vessel Disease; SIMA, Stenting versus Internal Mammary Artery grafting trial; SoS, Stent or Surgery Trial; CARDia, Coronary Artery Revascularization in Diabetes; FREEDOM, Future REvascularization Evaluation in patients with Diabetes mellitus: Optimal management of Multivessel disease; PRECOMBAT, Premier of Randomized Comparison of Bypass Surgery versus Angioplasty Using Sirolimus-Eluting Stent in Patients with Left Main Coronary Artery Disease; SYNTAX, Synergy Between Percutaneous Coronary Intervention With Taxus and Cardiac Surgery; $L M C A$, left main coronary artery. $\dagger$ Not reported, assumed to be $0 \%$. $\ddagger 3 \%$ of patients randomized to PCI were treated with a bare metal stents. $\S 2 \%$ of patients randomized to PCI were treated with angioplasty. $\| 13 \%$ of patients randomized to PCI were treated with angioplasty. $\uparrow 30 \%$ of patients randomized to PCI were treated with angioplasty. \#35\% of patients randomized to PCI were treated with drug-eluting stents. **28\% of patients randomized to PCI were treated with angioplasty. $\dagger \dagger$ Main stem or main stem equivalent lesions. Main-stem-equivalent lesions were defined as a leading proximal LAD stenosis or stenosis of an LAD bypass ( $\geq 75 \%$ ) with a concomitantly documented proximal occlusion of the right coronary artery and/or the left circumflex artery. $\$ \ddagger 22 \%$ of lesions of patients randomized to PCI were treated with angioplasty. $\S \S$ Drug-eluting stents used in $69 \%$ of patients randomized to PCI and bare metal stents in $31 \%$ of patients. ||||Bare metal stents used in $5 \%$ of patients randomized to PCI. $\uparrow \uparrow$ Either multivessel disease including the left anterior descending coronary artery or isolated proximal left anterior descending coronary artery disease. 
TABLE 2. Meta-analyzed ORs for outcomes at the latest available follow-up and per era, PCI versus CABG

\begin{tabular}{|c|c|c|c|c|c|}
\hline Outcome & OR $(95 \%$ CI $)$ & $P$ value & n & $\mathbf{I}^{2}(95 \% \mathbf{C I}), \%$ & $P$ value heterogeneity \\
\hline Mortality & $1.1(1.0-1.3)$ & .05 & 31 & $21.4(0-50)$ & .15 \\
\hline Pre-stent era & $1.2(1.0-1.3)$ & .06 & 9 & $0(0-65)$ & .48 \\
\hline Bare metal stent era & $1.0(0.8-1.3)$ & .95 & 14 & $12.5(0-51)$ & .32 \\
\hline Drug-eluting stent era & $1.2(0.9-1.7)$ & .21 & 8 & $43.8(0-75)$ & .09 \\
\hline Myocardial infarction & $1.2(0.9-1.5)$ & .28 & 28 & $59.1(38-73)$ & $<.01$ \\
\hline Pre-stent era & $1.2(0.8-1.8)$ & .43 & 7 & $49.8(0-79)$ & .06 \\
\hline Bare metal stent era & $0.9(0.6-1.4)$ & .78 & 13 & $29.9(0-64)$ & .15 \\
\hline Drug-eluting stent era & $1.4(0.9-2.4)$ & .18 & 8 & $65.0(25-84)$ & $<.01$ \\
\hline Repeat revascularization & $4.5(3.5-5.8)$ & $<.01 *$ & 31 & $78.3(70-84)$ & $<.01$ \\
\hline Pre-stent era & $7.0(5.1-9.7)$ & $<.01$ & 9 & $69.6(39-85)$ & $<.01$ \\
\hline Bare metal stent era & $4.5(3.6-5.5)$ & $<.01$ & 14 & $11.1(0-49)$ & .33 \\
\hline Drug-eluting stent era & $2.5(1.8-3.4)$ & $<.01$ & 8 & $47.1(0-76)$ & .07 \\
\hline Stroke & $0.7(0.5-0.9)$ & .01 & 12 & $0(0-58)$ & .67 \\
\hline Pre-stent era & $1.0(0.1-15.8)$ & .98 & 1 & $0^{\dagger}$ & 1.00 \\
\hline Bare metal stent era & $0.9(0.6-1.4)$ & .59 & 5 & $0(0-79)$ & .42 \\
\hline Drug-eluting stent era & $0.6(0.4-0.8)$ & $<.01$ & 6 & $0(0-75)$ & .84 \\
\hline Cardiac mortality & $1.2(0.9-1.6)$ & .13 & 15 & $27.3(0-61)$ & .16 \\
\hline Pre-stent era & $1.2(0.9-1.5)$ & .18 & 6 & $0(0-75)$ & .81 \\
\hline Bare metal stent era & $1.1(0.7-1.7)$ & .82 & 6 & $35.0(0-74)$ & .17 \\
\hline Drug-eluting stent era & $1.3(0.6-3.2)$ & .50 & 3 & $63.7(0-90)$ & .06 \\
\hline Angina-free survival & $0.7(0.6-0.9)$ & .01 & 16 & $60.9(33-77)$ & $<.01$ \\
\hline Pre-stent era & $0.7(0.6-0.9)$ & $<.01$ & 4 & $8.2(0-86)$ & .35 \\
\hline Bare metal stent era & $0.7(0.5-1.0)$ & .03 & 10 & $68.9(40-84)$ & $<.01$ \\
\hline Drug-eluting stent era & $1.2(0.8-1.7)$ & .40 & 2 & $0^{\dagger}$ & .47 \\
\hline
\end{tabular}

$O R$, Odds ratio; $C I$, confidence interval; $n$, number of studies included in the analysis. $*<.00000001 . \dagger 95 \%$ CI for $\mathrm{I}^{2}$ cannot be calculated for a meta-analysis of 1 or 2 studies

0.5 to 13 years (median, 5 years) with a median loss to follow-up of $0.5 \%$ (range, $0 \%-8.0 \%$ ). Arterial conduits were used ranging from $37 \%$ to $100 \%$ of all grafts. Thirteen trials exclusively used on-pump operating techniques; 9 trials exclusively used off-pump operating techniques; and 8 trials used a mix of on- and off-pump operating techniques, with a median of $18.8 \%$ (range, 3\%-64\%) off-pump use across these trials. For 1 trial, information on the operating technique was not available.

\section{Trial Quality}

All trials randomized patients; 12 out of 31 trials specifically mentioned the use of computer-generated random numbers or random number tables. The other 19 trials did not mention the sequence-generation method. Fourteen out of 31 trials reported adequate procedures to conceal allocation. Twenty-nine out of 31 studies had few exclusions after randomization, whereas none of the trials was triple blind (with blinding of participants, health care providers, and outcome assessors). In 9 of the 31 trials, the outcome assessors were blinded; in 22 of the 31 trials, no blinding at all occurred. Trial quality is presented in detail in a table in Appendix E1.

\section{Meta-Analysis of Outcomes Across All 31 Selected Trials, per Era and per Time Period of Follow-up}

Table 2 gives an overview of the outcomes at the latest available follow-up (forest plots are shown in Appendix E1). The odds for mortality were higher for PCI compared to $\mathrm{CABG}$ across all studies (OR, 1.1; 95\% CI, 1.0-1.3; $P=.05)$, but not in each era separately. The odds for myocardial infarction did not differ significantly (OR, 1.2; $95 \% \mathrm{CI}, 0.9-1.5 ; P=.28$ ) across all studies and eras, nor in each era separately. Repeat revascularization was more common across all eras (OR, 4.5; 95\% CI, 3.5-5.8; $P<.01)$ and in each era separately. The large heterogeneity across all eras $\left(\mathrm{I}^{2}=78.3 \%\right)$ was due to a decline in the ORs for repeat revascularization, with progressively less difference in ORs from the pre-stent era to the drug-eluting stent era (in meta-regression, there was interaction between the year of the study's start and the OR for repeat revascularization (coefficient, $-0.06(95 \%$ CI, -0.08 to $-0.03 ; P<.01)$. The odds for stroke were lower after PCI compared to CABG across all eras (OR, $0.7 ; 95 \% \mathrm{CI}, 0.5-0.9 ; P=.01)$ and in the drug-eluting stent era (OR, $0.6 ; 95 \%$ CI, $0.4-0.8 ; P<.01)$, but not in the bare metal stent era (only 1 trial provided data on the outcome stroke in the pre-stent era). Cardiac mortality was as common after PCI across all eras (OR, 1.2; 95\% CI, $0.9-1.6 ; P=.13)$. Angina-free survival was less common after PCI (OR, 0.7; 95\% CI, 0.6-0.9; $P=.01)$ across all eras and in the pre-stent and stent eras, but not in the drug-eluting stent era.

We found no evidence of publication bias for the main outcomes across all studies, neither on visual inspection nor by using Duval and Tweedie's trim and fill test. Sensitivity analyses did not give evidence of a differential 
TABLE 3. Meta-analyzed ORs for outcomes in patients with different types of vessel disease at the latest available follow-up across all eras, PCI versus CABG

\begin{tabular}{|c|c|c|c|c|c|}
\hline Outcome & OR $(95 \% \mathrm{CI})$ & $P$ value & $\mathbf{n}$ & $\mathbf{I}^{2}(95 \% \mathbf{C I}), \%$ & $P$ value heterogeneity \\
\hline \multicolumn{6}{|l|}{ Mortality } \\
\hline Multivessel disease & $1.2(1.0-1.4)$ & .02 & 12 & $18.3(0-58)$ & .26 \\
\hline Proximal LAD stenosis & $1.0(0.7-1.6)$ & .95 & 11 & $0(0-60)$ & .61 \\
\hline Main stem stenosis & $0.8(0.5-1.2)$ & .27 & 4 & $0(0-85)$ & .99 \\
\hline \multicolumn{6}{|l|}{ Myocardial infarction } \\
\hline Multivessel disease & $1.1(0.8-1.6)$ & .6 & 10 & $71.2(45-85)$ & $<.01$ \\
\hline Proximal LAD stenosis & $1.2(0.6-2.4)$ & .55 & 10 & $35(0-69)$ & .13 \\
\hline Main stem stenosis & $1.4(0.5-3.7)$ & .48 & 4 & $0(0-85)$ & .58 \\
\hline \multicolumn{6}{|l|}{ Repeat revascularization } \\
\hline Multivessel disease & $5.6(4.2-7.4)$ & $<.01$ & 12 & $77.3(61-87)$ & $<.01$ \\
\hline Proximal LAD stenosis & $5.7(3.5-9.1)$ & $<.01$ & 11 & $10.1(0-50)$ & .39 \\
\hline Main stem stenosis & $2.8(1.7-4.5)$ & $<.01$ & 4 & $0(0-85)$ & .63 \\
\hline \multicolumn{6}{|l|}{ Stroke } \\
\hline Multivessel disease & $0.6(0.4-1.1)$ & .11 & 4 & $46.9(0-82)$ & .13 \\
\hline Proximal LAD stenosis & $1.2(0.2-6.9)$ & .83 & 3 & $0(0-90)$ & .47 \\
\hline Main stem stenosis & $0.4(0.1-1.8)$ & .23 & 3 & $0(0-90)$ & .87 \\
\hline
\end{tabular}

$O R$, Odds ratio; $C I$, confidence interval; $n$, number of studies included in the analysis; $L A D$, left anterior descending coronary artery.

effect in studies with different quality scores in the domains of randomization, concealment, and blinding, nor was there a differential effect when studies in which $10 \%$ or more of patients were treated with a different type of PCI were excluded (data not shown).

In the analyses of the main outcomes at different time points of follow-up, at 5 years of follow-up, significantly fewer patients died after $\mathrm{CABG}$, compared to PCI (OR, 1.3; 95\% CI, 1.1-1.5; $P<.01$ ) (see Appendix E1 for figures of the primary outcomes meta-analyzed at $0.5,1,1.5$ $2,2.5-3,4$, and 5 years). At 1 to 4 years of follow-up, the ORs for death were hovering around 1; at 6 months, the OR for death was $0.6(95 \% \mathrm{CI}, 0.2-1.7 ; P=.31)$. After 4 and 5 years of follow-up, significantly fewer CABG patients got a myocardial infarction, compared to PCI patients (OR, 2.4; 95\% CI, 1.6-3.6; $P<.01$; and OR, 1.6; $95 \%$ CI, 1.1-2.3; $P=.01$, respectively). At each time point of follow-up, there were significantly fewer repeat revascularizations after $\mathrm{CABG}(P \leq .01$ at each time point). At a time period of 1-year follow-up, stroke was significantly less frequent in the PCI group (OR, 0.5; 95\% CI, 0.3-0.7; $P<.01)$ but not at the other time periods of follow-up.

\section{Outcomes in Patients With Different Types of Diseased Vessels}

Twelve trials evaluated patients with multivessel disease, 11 trials analyzed patients with proximal LAD stenosis and 4 trials analyzed patients with left main stenosis (Table 3). All-cause death was higher after PCI compared to surgery in multivessel disease (OR, 1.2; 95\% CI, 1.0-1.4; $P=.02$ ), but not in proximal LAD stenosis or left main stenosis. Myocardial infarction did not occur significantly more often after PCI compared to CABG in patients with multivessel disease, proximal LAD stenosis, or left main stenosis. Repeat revascularization favored $\mathrm{CABG}$ in multivessel disease, proximal LAD stenosis, and main stem stenosis patients. The OR for repeat revascularization

TABLE 4. Meta-analyzed ORs for outcomes in patients with on- and off-pump surgery at the latest available follow-up, in the bare metal stent and drug-eluting stent eras, PCI versus CABG

\begin{tabular}{|c|c|c|c|c|c|}
\hline Outcome & OR $(95 \%$ CI $)$ & $P$ value & $\mathbf{n}$ & $\mathbf{I}^{2}(95 \%$ CI $), \%$ & $P$ value heterogeneity \\
\hline \multicolumn{6}{|l|}{ Mortality } \\
\hline On-pump surgery & $0.9(0.7-1.2)$ & .40 & 4 & $0(0-85)$ & .50 \\
\hline Off-pump surgery & $0.8(0.5-1.3)$ & .34 & 9 & $0(0-65)$ & .52 \\
\hline \multicolumn{6}{|l|}{ Myocardial infarction } \\
\hline On-pump surgery & $1.0(0.6-1.9)$ & .94 & 4 & $58.8(0-86)$ & .06 \\
\hline Off-pump surgery & $0.8(0.4-1.6)$ & .13 & 8 & $18.9(0-62)$ & .28 \\
\hline \multicolumn{6}{|c|}{ Repeat revascularization } \\
\hline On-pump surgery & $5.3(3.8-7.3)$ & $<.01$ & 4 & $26.4(0-72)$ & .25 \\
\hline Off-pump surgery & $3.2(2.2-4.7)$ & $<.01$ & 9 & $0(0-65)$ & .67 \\
\hline \multicolumn{6}{|l|}{ Stroke } \\
\hline On-pump surgery & $0.8(0.5-1.4)$ & .54 & 3 & $10.8(0-91)$ & .33 \\
\hline Off-pump surgery & $1.4(0.1-20.6)$ & .82 & 2 & $32.8 *$ & .22 \\
\hline
\end{tabular}

$O R$, Odds ratio; $C I$, confidence interval; $n$, number of studies included in the analysis. $* 95 \%$ CI for $\mathrm{I}^{2}$ cannot be calculated for a meta-analysis of 1 or 2 studies. 
TABLE 5. Meta-analyzed ORs for outcomes in diabetes patients at the latest available follow-up across all eras, PCI versus CABG

\begin{tabular}{|c|c|c|c|c|c|}
\hline Outcome & OR $(95 \%$ CI $)$ & $P$ value & $\mathbf{n}$ & $\mathbf{I}^{2}(\mathbf{9 5} \% \mathbf{C I}), \%$ & $P$ value heterogeneity \\
\hline Mortality & $1.6(1.2-2.1)$ & $<.01$ & 12 & $27.4(0-63)$ & .18 \\
\hline Pre-stent era & $1.5(0.8-2.8)$ & .26 & 4 & $49.6(0-83)$ & .11 \\
\hline Bare metal stent era & $1.6(1.0-2.5)$ & .07 & 4 & $0.3(0-85)$ & .39 \\
\hline Drug-eluting stent era & $1.7(1.1-2.6)$ & .02 & 4 & $51.6(0-84)$ & .10 \\
\hline Myocardial infarction & $1.2(0.8-2.0)$ & .33 & 7 & $64.4(20-84)$ & .01 \\
\hline Pre-stent era & $1.1(0.6-1.9)$ & .75 & 1 & $0^{*}$ & 1.00 \\
\hline Bare metal stent era & $1.0(0.3-2.7)$ & .93 & 2 & $44.5^{*}$ & .18 \\
\hline Drug-eluting stent era & $1.4(0.7-2.6)$ & .34 & 4 & $74.0(28-91)$ & $<.01$ \\
\hline Repeat revascularization & $3.4(2.1-5.7)$ & $<.01$ & 6 & $72.0(35-88)$ & $<.01$ \\
\hline Pre-stent era & - & - & 0 & - & - \\
\hline Bare metal stent era & $6.3(3.3-11.8)$ & $<.01$ & 2 & $0^{*}$ & .89 \\
\hline Drug-eluting stent era & $2.7(1.5-4.9)$ & $<.01$ & 4 & $67.0(0-90)$ & $<.01$ \\
\hline Stroke & $0.5(0.3-0.8)$ & .01 & 4 & $0(0-85)$ & .60 \\
\hline Pre-stent era & - & - & 0 & - & - \\
\hline Bare metal stent era & - & - & 0 & - & - \\
\hline Drug-eluting stent era & $0.5(0.3-0.8)$ & .01 & 4 & $0(0-85)$ & .60 \\
\hline
\end{tabular}

$O R$, Odds ratio; $C I$, confidence interval; $n$, number of studies included in the analysis. $* 95 \%$ CI for $\mathrm{I}^{2}$ cannot be calculated for a meta-analysis of 1 or 2 studies.

was around twice as high for multivessel disease (OR, 5.6; 95\% CI, 4.2-7.4) and proximal LAD stenosis patients (OR, $5.7 ; 95 \%$ CI, 3.5-9.1), compared to patients with main stem stenosis (OR, 2.8; 95\% CI, 1.7-4.5). Differences in stroke rate were not significant in either patient group.

\section{Outcomes in Off-Pump Versus On-Pump Surgery}

We excluded all trials from the pre-stent era, as in none of these studies off-pump surgery was used. In the bare metal stent and drug-eluting stent eras, 4 trials used on-pump surgery exclusively, whereas 9 trials used off-pump surgery exclusively. There was no significant difference between CABG and PCI in mortality, myocardial infarction, and stroke when off-pump surgery was used, or even when on-pump surgery was used (Table 4). The meta-analyzed primary outcomes did not differ between off-pump and on-pump surgery. Only 2 (Drenth and Kim) out of 9 trials that used off-pump surgery exclusively reported on stroke as an outcome. Stroke was not more common after CABG in these 2 studies (OR, 1.4; 95\% CI, 0.1-20.6; $P=.82)$.

\section{Outcomes in (Subgroups of) Patients With Diabetes}

Twelve trials provided data on patients with diabetes separately, usually as a subgroup except for the CARDia, Future REvascularization Evaluation in patients with Diabetes mellitus: Optimal management of Multivessel disease (FREEDOM), and Veterans Affairs trials that included patients with diabetes exclusively. The OR for death favored $\mathrm{CABG}$ at the latest available follow-up across all 12 studies (OR, 1.6; 95\% CI, 1.2-2.1; $P<.01$ ), as well as in the drug-eluting stent era (OR, 1.7; 95\% CI, 1.1-2.6, $P=.01$ ) (Table 5). Myocardial infarctions did not differ significantly. Repeat revascularization in patients with diabetes occurred more frequently after PCI compared to CABG (OR, 3.4; 95\% CI, 2.1-5.7; $P<.01$ ). Data on stroke in patients with diabetes were only available for the drug-eluting stent era and occurred less frequently after PCI (OR, 0.5; 95\% CI, 0.3-0.8; $P=.01$ ). Effect sizes were similar-though differences were not always statistically significant-if only randomized data on patients with diabetes were meta-analyzed (ie, subgroup data were left out of the meta-analysis) with an OR for death of $1.8(95 \% \mathrm{CI}, 0.8-3.8 ; P=.14)$; myocardial infarction 1.2 (95\% CI, 0.5-3.0; $P=.65$ ); repeat revascularization 2.6 (95\% CI, 1.0-6.4; $P=.05)$; and stroke 0.5 (95\% CI, 0.3 $0.8 ; P=.01$ ). In patients without diabetes (data from subgroups only), there was no difference in mortality (OR, 1.0; 95\% CI, 0.9-1.2;P=.74) or myocardial infarction (OR, $1.0 ; 95 \% \mathrm{CI}, 0.7-1.5 ; P=.95)$. Only 8 trials provided data on subgroups of patients without diabetes. All these 8 trials were from the pre-stent era ( 5 trials) or the bare metal stent era ( 3 trials). Only 2 of them provided data on repeat revascularization; therefore, we did not meta-analyze repeat revascularization for patients without diabetes, and none of them provided stroke data.

\section{DISCUSSION}

To our knowledge, this meta-analysis is the most up-to-date and complete overview of the effectiveness of PCI versus CABG as revascularization strategies for patients with coronary artery disease. This meta-analysis includes 31 trials with 15,004 patients. Our main findings are that $\mathrm{CABG}$ led to a small survival benefit over PCI. This survival difference benefits patients with multivessel disease and patients with diabetes, respectively. In addition, repeat revascularization was less common after $\mathrm{CABG}$, though PCI is narrowing the gap over time. Stroke was more common after CABG.

Composite endpoints of major adverse cardiac and cerebrovascular events were not used. First, composite 
endpoints are not uniformly defined across trials, which leads to loss of information if only a subset of composite endpoints can be meta-analyzed. Second, when included in a composite endpoint, repeat revascularization dominates the other composites as they occur at a much higher rate. Third, there is now evidence that from a patient's perspective the components of composite endpoints are not equally important. Patients found the risk of death to be the most important outcome (relative weight 0.23), followed by stroke (0.18), potential increased longevity and recovery time (each 0.17), myocardial infarction (0.14), and risk of repeat revascularization (0.11). E119

Our study is limited by the fact that we did not have access to individual patient data, and analyzed patients at group level. It is more difficult to unravel the complex interactions of different patient-related factors (type of PCI or CABG, type of vessel involvement, time of follow-up, subgroups involved) that influence outcomes, when less detailed information is available. Therefore, results should be interpreted with caution. For example, that we found a (nonsignificant) higher myocardial infarction rate after PCI in the drugeluting stent era may be confounded by diabetes, as 3 of the 8 trials in the drug-eluting stent era were in patients with diabetes exclusively. In addition, subgroup analyses may have been underpowered; many trials did not provide data on subgroups of interest. Subgroup analyses may best be seen as hypothesis generating as patients were usually not randomized according to the subgroups of interest. As an example, the difference in mortality between PCI and CABG is not apparent when studies that used off-pump or on-pump CABG exclusively were analyzed separately. In addition, we tested a lot of hypotheses, which makes the chance of a spurious finding higher. As a remedy, a stricter cut-off for statistical significance (eg, 0.01) might be used. If we had used a cut-off of 0.01 the higher all-cause death after PCI compared to surgery in multivessel disease would be nonsignificant.

Another limitation is that only few studies (12 of 31 trials) provided data on stroke. Notably, only 2 of 9 trials that used off-pump surgery exclusively provided stroke data. As the risk of stroke is lower after off-pump CABG, compared to on-pump $\mathrm{CABG},{ }^{\mathrm{E} 120}$ the difference in stroke risk in our meta-analysis may have been overestimated in favor of PCI.

Heterogeneous definitions of myocardial infarction and stroke further complicate the interpretation of our findings.

Because we did not perform a survival analysis, the meta-analyzed ORs for myocardial infarction and repeat revascularization might be overestimated. We did not estimate the numbers at risk for each time point of followup or a time-to event analysis. If we wanted to metaanalyze hazard ratios, we would have to leave out several trials for each outcome, as not all trials performed time-to-event analyses. For example, of the 7 trials with a follow-up of 8 years or longer, 4 trials had information missing that was needed to calculate hazard ratios for some outcomes, including 2 trials where such information was missing for the outcome death. However, because the number of deaths was small, especially in those studies with a follow-up of $<5$ years, and because the loss to follow-up was small at a median of $0.5 \%$, we feel that the method used is sound.

The generalizability of our findings is limited by the fact that only a very small proportion (median, $7.8 \%$ ) of screened patients were randomized. Exclusion criteria were usually very strict; for example, patients with a recent myocardial infarction, a low left ventricular ejection fraction, or a prior $\mathrm{PCI} / \mathrm{CABG}$ procedure could not participate. The range of patients that is included in the RCTs is also limited because patients have to be eligible for both PCI and CABG. In real life, many patients with coronary artery disease will not be eligible for both procedures as, for example, PCI is not technically feasible or because they have contraindications for CABG. Fortunately, the most recent trials included a much higher proportion of screened patients, with trials on drugeluting stents including a median of $41 \%$ of screened patients (range, $3 \%-61 \%$ ).

The Synergy Between Percutaneous Coronary Intervention With Taxus and Cardiac Surgery (SYNTAX) score has the potential to further refine the optimal treatment strategy for individual patients. Today, knowledge on the best treatment strategy in view of individual SYNTAX scores stems from the SYNTAX study only, and needs to be further elucidated. The ongoing EXCEL trial is designed to further evaluate one of the outstanding questions the SYNTAX trial raised: Do patients with left main disease and a SYNTAX score $\leq 32$ benefit more from PCI than from CABG?

\section{CONCLUSIONS}

Compared with PCI, CABG had a lower risk of death or repeat revascularization but a higher risk of stroke. The smaller risk of death favors patients with multivessel disease or with diabetes.

Our findings are valid in settings and in patients comparable to those of the original PCI versus CABG trials: high-volume, state-of-the-art cardiac centers where patient treatment is discussed and decided upon by a team of interventional cardiologists and cardiac surgeons, and in highly selective patients eligible for either intervention. The results do not necessarily apply to other settings or patients.

\section{Conflict of Interest Statement}

Massimo A. Mariani reports consulting fees from Sorin and lecture fees from Sorin and Maquet. All other authors have nothing to disclose with regard to commercial support.

We would like to thank Gerry Ligtenberg, Carina Parmentier, and Desiree Welten for their constructive comments in various stages of our research. 


\section{APPENDIX E1}

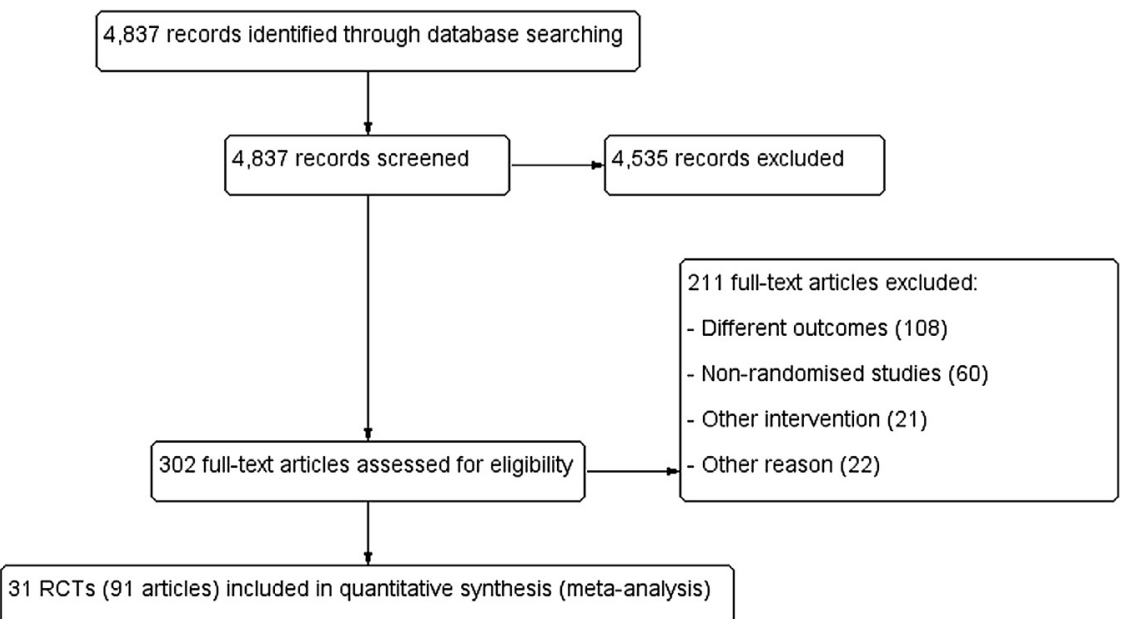

FIGURE E1. Flow diagram of the search and selection process. $R C T$, Randomized controlled trial. 


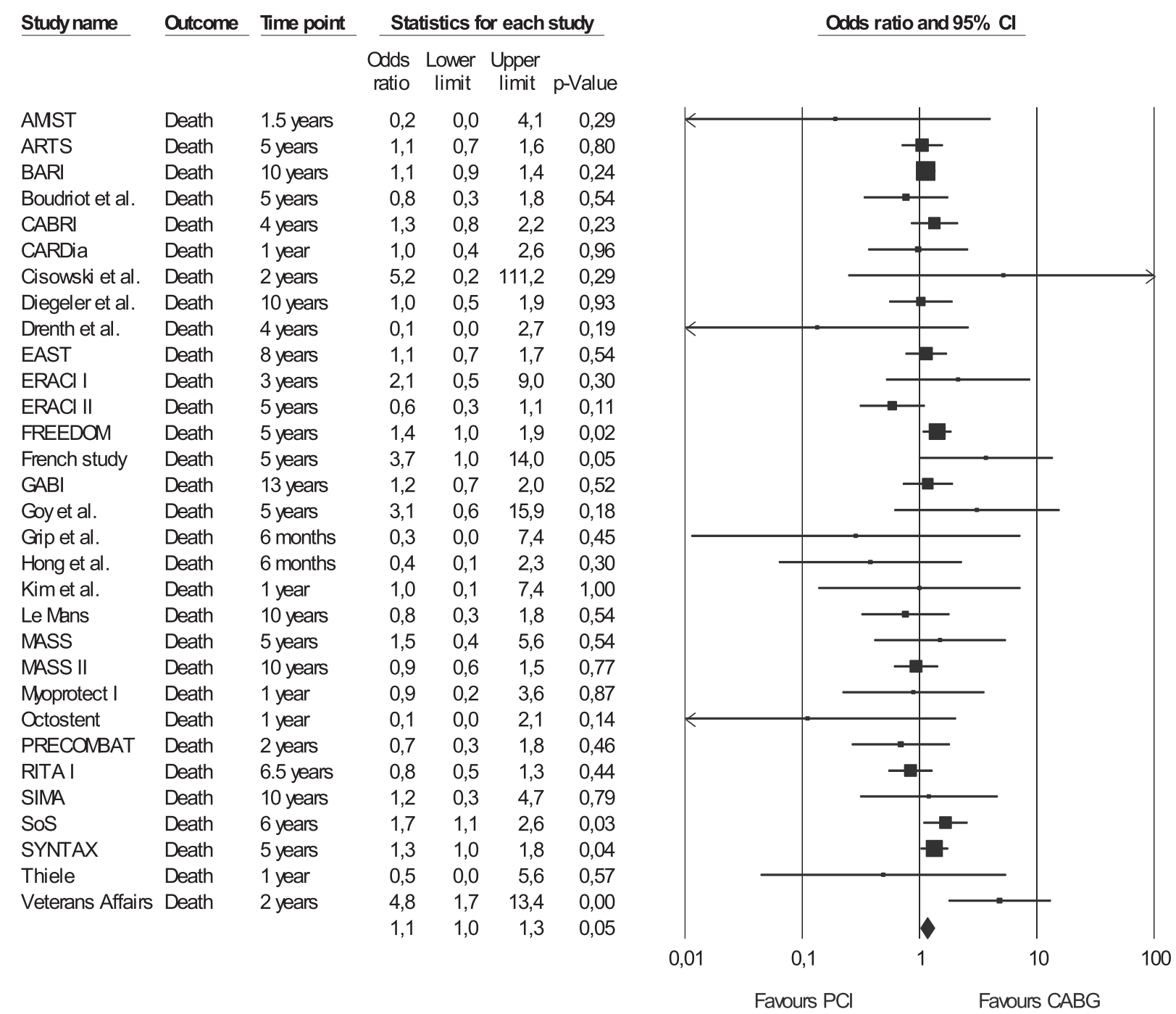

FIGURE E2. Meta-analyzed odds ratios for death after PCI or CABG at the latest available follow-up. PCI, Percutaneous coronary intervention; $C A B G$, coronary artery bypass grafting; $C I$, confidence interval; AMIST, Angioplasty versus Minimally Invasive Surgery Trial; ARTS, Arterial Revascularization Therapies Study; BARI, Bypass Angioplasty Revascularization Investigation; CABRI, Coronary Angioplasty versus Bypass Revascularisation Investigation; EAST, Emory Angioplasty versus Surgery Trial; ERACI I, Argentine Randomized Trial of Percutaneous Transluminal Coronary Angioplasty Versus Coronary Artery Bypass Surgery in Multivessel Disease; GABI, German Angioplasty Bypass Surgery Investigation; MASS, Medicine, Angioplasty, or Surgery Study; RITA, Randomised Intervention Treatment of Angina; ERACI II, Argentine Randomized Trial of Coronary Angioplasty With Stenting Versus Coronary Bypass Surgery in Patients with Multiple Vessel Disease; SIMA, Stenting versus Internal Mammary Artery grafting trial; SoS, Stent or Surgery Trial; CARDia, Coronary Artery Revascularization in Diabetes; FREEDOM, Future REvascularization Evaluation in patients with Diabetes mellitus: Optimal management of Multivessel disease; PRECOMBAT, Premier of Randomized Comparison of Bypass Surgery versus Angioplasty Using Sirolimus-Eluting Stent in Patients with Left Main Coronary Artery Disease; SYNTAX, Synergy Between Percutaneous Coronary Intervention With Taxus and Cardiac Surgery. 


\begin{tabular}{|c|c|c|c|c|c|c|}
\hline \multirow[t]{2}{*}{ Study name } & \multirow[t]{2}{*}{ Outcome } & \multirow[t]{2}{*}{ Time point } & \multicolumn{4}{|c|}{ Statistics for each study } \\
\hline & & & $\begin{array}{l}\text { Odds } \\
\text { ratio }\end{array}$ & $\begin{array}{l}\text { Lower } \\
\text { limit }\end{array}$ & $\begin{array}{l}\text { Upper } \\
\text { limit }\end{array}$ & $p$-Value \\
\hline AMST & M & 1.5 years & 5,2 & 0,2 & 111,2 & 0,29 \\
\hline ARTS & $M$ & 5 years & 1,3 & 0,9 & 2,1 & 0,18 \\
\hline Boudriot et al. & M & 5 years & 2,1 & 0,4 & 11,5 & 0,41 \\
\hline CABRI & Non-fatal M & 1 year & 1,4 & 0,8 & 2,7 & 0,24 \\
\hline CARDia & Non-fatal M & 1 year & 1,8 & 0,9 & 3,6 & 0,08 \\
\hline Cisowski et al. & M & 2 years & 3,1 & 0,1 & 76,9 & 0,50 \\
\hline Diegeler et al. & M & 10 years & 0,4 & 0,1 & 1,1 & 0,08 \\
\hline Drenth et al. & M & 4 years & 5,4 & 0,6 & 48,3 & 0,13 \\
\hline EAST & Q-wave M & 3 years & 0,7 & 0,4 & 1,2 & 0,20 \\
\hline ERACI I & Q-wave M & 3 years & 1,0 & 0,3 & 3,7 & 0,98 \\
\hline ERACI II & Non-fatal Q-wave M & 5 years & 0,4 & 0,2 & 1,1 & 0,08 \\
\hline FREEDOM & M & 5 years & 2,1 & 1,5 & 3,1 & 0,00 \\
\hline GABI & Q-wave M & 1 year & 0,5 & 0,2 & 1,3 & 0,16 \\
\hline Goy et al. & M & 5 years & 3,6 & 0,9 & 13,8 & 0,06 \\
\hline Grip et al. & Q-wave M & 6 months & 0,9 & 0,1 & 15,0 & 0,93 \\
\hline Hong et al. & M & 6 months & 0,9 & 0,2 & 3,2 & 0,84 \\
\hline Le Mans & Non-fatal M & 1 year & 0,3 & 0,0 & 3,2 & 0,34 \\
\hline MASS & M & 5 years & 2,1 & 0,6 & 7,2 & 0,26 \\
\hline MASS II & Non-fatal M & 5 years & 1,7 & 0,9 & 3,0 & 0,09 \\
\hline Myoprotect I & M & 1 year & 2,9 & 0,1 & 74,3 & 0,53 \\
\hline Octostent & M & 1 year & 0,9 & 0,3 & 2,7 & 0,82 \\
\hline PRECOMBAT & M & 2 years & 1,7 & 0,4 & 7,1 & 0,48 \\
\hline RITA I & Non-fatal M & 6.5 years & 1,5 & 1,0 & 2,3 & 0,06 \\
\hline SIMA & M & 10 years & 0,9 & 0,2 & 4,9 & 0,95 \\
\hline Sos & Q-wave M & 2 years & 0,6 & 0,4 & 1,0 & 0,07 \\
\hline SYNTAX & M & 5 years & 2,6 & 1,7 & 4,0 & 0,00 \\
\hline Thiele & Non-fatal M & 1 year & 0,2 & 0,0 & 1,7 & 0,13 \\
\hline Veterans Affairs & Non-fatal M & 2 years & 0,3 & 0,1 & 0,9 & 0,04 \\
\hline & & & 1,2 & 0,9 & 1,5 & 0,28 \\
\hline
\end{tabular}

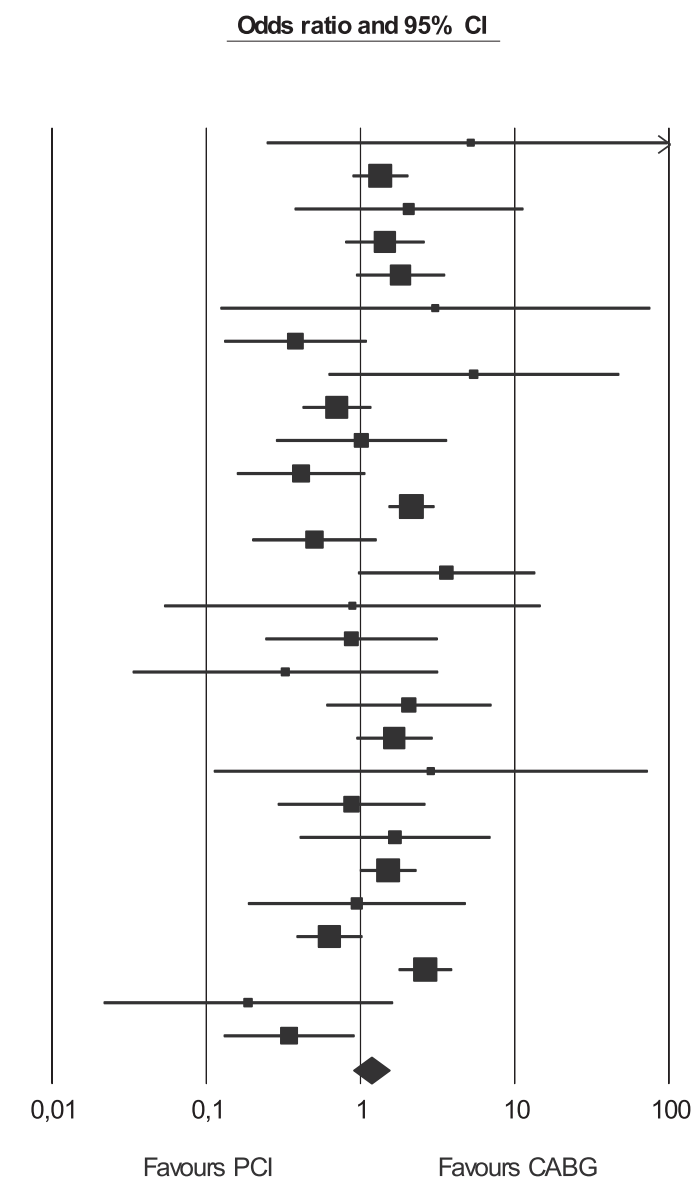

FIGURE E3. Meta-analyzed odds ratios for myocardial infarction after PCI or CABG at the latest available follow-up. PCI, Percutaneous coronary intervention; $C A B G$, coronary artery bypass grafting; $C I$, confidence interval; $M I$, myocardial infarction; $A M I S T$, Angioplasty versus Minimally Invasive Surgery Trial; ARTS, Arterial Revascularization Therapies Study; CABRI, Coronary Angioplasty versus Bypass Revascularisation Investigation; EAST, Emory Angioplasty versus Surgery Trial; ERACI I, Argentine Randomized Trial of Percutaneous Transluminal Coronary Angioplasty Versus Coronary Artery Bypass Surgery in Multivessel Disease; GABI, German Angioplasty Bypass Surgery Investigation; MASS, Medicine, Angioplasty, or Surgery Study; RITA, Randomised Intervention Treatment of Angina; ERACI II, Argentine Randomized Trial of Coronary Angioplasty With Stenting Versus Coronary Bypass Surgery in Patients with Multiple Vessel Disease; SIMA, Stenting versus Internal Mammary Artery grafting trial; SoS, Stent or Surgery Trial; CARDia, Coronary Artery Revascularization in Diabetes; FREEDOM, Future REvascularization Evaluation in patients with Diabetes mellitus: Optimal management of Multivessel disease; PRECOMBAT, Premier of Randomized Comparison of Bypass Surgery versus Angioplasty Using SirolimusEluting Stent in Patients with Left Main Coronary Artery Disease; SYNTAX, Synergy Between Percutaneous Coronary Intervention With Taxus and Cardiac Surgery. 


\begin{tabular}{|c|c|c|c|c|c|c|}
\hline \multirow[t]{2}{*}{ Study name } & \multirow[t]{2}{*}{ Outcome } & \multirow[t]{2}{*}{ Time point } & \multicolumn{4}{|c|}{ Statistics for each study } \\
\hline & & & $\begin{array}{l}\text { Odds } \\
\text { ratio }\end{array}$ & $\begin{array}{c}\text { Lower } \\
\text { limit }\end{array}$ & $\begin{array}{l}\text { Upper } \\
\text { limit }\end{array}$ & p-Value \\
\hline AMST & $\mathrm{RR}$ & 1.5 years & 5,2 & 0,2 & 111,2 & 0,29 \\
\hline ARTS & $\mathrm{RR}$ & 5 years & 4,5 & 3,3 & 6,3 & 0,00 \\
\hline BARI & $R R$ & 10 years & 7,9 & 6,4 & 9,8 & 0,00 \\
\hline Boudriot et al. & $\mathrm{RR}$ & 5 years & 2,6 & 1,1 & 5,9 & 0,03 \\
\hline CABRI & $\mathrm{RR}$ & 4 years & 9,4 & 6,5 & 13,5 & 0,00 \\
\hline CARDia & $\mathrm{RR}$ & 1 year & 6,5 & 2,5 & 17,1 & 0,00 \\
\hline Cisowski et al. & $R R$ & 1 year & 5,5 & 1,5 & 20,8 & 0,01 \\
\hline Diegeler et al. & TVR & 10 years & 4,3 & 2,1 & 9,1 & 0,00 \\
\hline Drenth et al. & TVR & 4 years & 4,6 & 0,9 & 22,6 & 0,06 \\
\hline EAST & $\mathrm{RR}$ & 3 years & 7,3 & 4,4 & 12,1 & 0,00 \\
\hline ERACI I & $\mathrm{RR}$ & 3 years & 8,6 & 2,8 & 26,8 & 0,00 \\
\hline ERACl II & $\mathrm{RR}$ & 5 years & 4,9 & 2,7 & 8,6 & 0,00 \\
\hline FREEDOM & $R R$ & 1 year & 3,0 & 2,1 & 4,3 & 0,00 \\
\hline French study & $\mathrm{RR}$ & 5 years & 8,1 & 2,3 & 28,8 & 0,00 \\
\hline GABI & $\mathrm{RR}$ & 13 years & 2,6 & 1,7 & 4,1 & 0,00 \\
\hline Goyet al. & $\mathrm{RR}$ & 5 years & 11,9 & 4,5 & 31,3 & 0,00 \\
\hline Gip et al. & $\mathrm{RR}$ & 6 months & 0,9 & 0,2 & 4,8 & 0,88 \\
\hline Hong et al. & TVR & 6 months & 2,4 & 0,3 & 21,9 & 0,44 \\
\hline Kim et al. & $\mathrm{RR}$ & 1 year & 8,0 & 0,9 & 67,5 & 0,06 \\
\hline Le Mans & $\mathrm{RR}$ & 1 year & 3,9 & 1,3 & 11,7 & 0,02 \\
\hline MASS & $\mathrm{RR}$ & 3 years & 58,9 & 3,5 & 994,3 & 0,00 \\
\hline MASS II & $\mathrm{RR}$ & 10 years & 8,9 & 4,9 & 16,1 & 0,00 \\
\hline Myoprotect I & $\mathrm{RR}$ & 1 year & 8,7 & 1,0 & 78,7 & 0,05 \\
\hline Octostent & $\mathrm{RR}$ & 7.5 years & 2,5 & 1,5 & 4,3 & 0,00 \\
\hline PRECOMBAT & $\mathrm{RR}$ & 2 years & 2,3 & 1,1 & 4,6 & 0,02 \\
\hline RITA I & $R R$ & 6.5 years & 6,6 & 4,7 & 9,2 & 0,00 \\
\hline SIMA & $\mathrm{RR}$ & 10 years & 7,6 & 2,1 & 27,6 & 0,00 \\
\hline Sos & $\mathrm{RR}$ & 2 years & 4,1 & 2,7 & 6,3 & 0,00 \\
\hline SYNTAX & $\mathrm{RR}$ & 5 years & 2,3 & 1,8 & 2,9 & 0,00 \\
\hline Thiele & TVR & 1 year & 9,6 & 0,5 & 181,8 & 0,13 \\
\hline Veterans Affairs & $\mathrm{RR}$ & 2 years & 1,0 & 0,5 & 1,9 & 0,89 \\
\hline & & & 4,5 & 3,5 & 5,8 & 0,00 \\
\hline
\end{tabular}

Odds ratio and $95 \% \mathrm{Cl}$

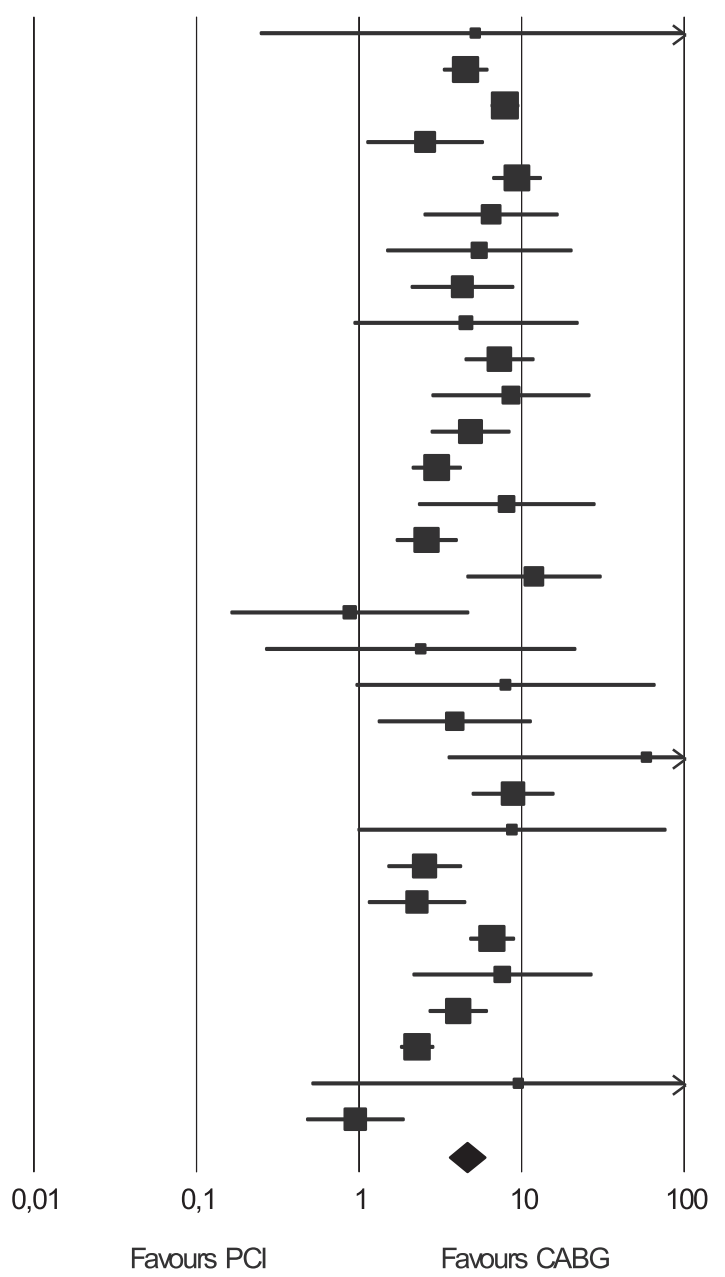

FIGURE E4. Meta-analyzed odds ratios for repeat revascularization after PCI or CABG at the latest available follow-up. PCI, Percutaneous coronary intervention; $C A B G$, coronary artery bypass grafting; $C I$, confidence interval; $R R$, repeat revascularization; TVR, target vessel revascularization; $A M I S T$, Angioplasty versus Minimally Invasive Surgery Trial; ARTS, Arterial Revascularization Therapies Study; BARI, Bypass Angioplasty Revascularization Investigation; CABRI, Coronary Angioplasty versus Bypass Revascularisation Investigation; EAST, Emory Angioplasty versus Surgery Trial; ERACI I, Argentine Randomized Trial of Percutaneous Transluminal Coronary Angioplasty Versus Coronary Artery Bypass Surgery in Multivessel Disease; GABI, German Angioplasty Bypass Surgery Investigation; MASS, Medicine, Angioplasty, or Surgery Study; RITA, Randomised Intervention Treatment of Angina; ERACI II, Argentine Randomized Trial of Coronary Angioplasty With Stenting Versus Coronary Bypass Surgery in Patients with Multiple Vessel Disease; SIMA, Stenting versus Internal Mammary Artery grafting trial; SoS, Stent or Surgery Trial; CARDia, Coronary Artery Revascularization in Diabetes; FREEDOM, Future REvascularization Evaluation in patients with Diabetes mellitus: Optimal management of Multivessel disease; PRECOMBAT, Premier of Randomized Comparison of Bypass Surgery versus Angioplasty Using Sirolimus-Eluting Stent in Patients with Left Main Coronary Artery Disease; SYNTAX, Synergy Between Percutaneous Coronary Intervention With Taxus and Cardiac Surgery. 


\begin{tabular}{|c|c|c|c|c|c|c|}
\hline \multirow[t]{2}{*}{ Study name } & \multirow[t]{2}{*}{ Outcome } & \multirow[t]{2}{*}{ Time point } & \multicolumn{4}{|c|}{ Statistics for each study } \\
\hline & & & $\begin{array}{l}\text { Odds } \\
\text { ratio }\end{array}$ & $\begin{array}{c}\text { Lower } \\
\text { limit }\end{array}$ & $\begin{array}{c}\text { Upper } \\
\text { limit }\end{array}$ & p-Value \\
\hline ARTS & Stroke & 5 years & 1,1 & 0,6 & 2,0 & 0,74 \\
\hline Boudriot et al. & Stroke & 5 years & 0,5 & 0,0 & 5,6 & 0,57 \\
\hline CARDia & Non-fatal stroke & 1 year & 0,1 & 0,0 & 1,1 & 0,06 \\
\hline Drenth et al. & Stroke & 4 years & 5,2 & 0,2 & 111,1 & 0,29 \\
\hline FREEDOM & Stroke & 5 years & 0,5 & 0,3 & 0,9 & 0,02 \\
\hline Kim et al. & Stroke & 1 year & 0,3 & 0,0 & 8,2 & 0,5 \\
\hline Le Mans & Stroke & 1 year & 0,2 & 0,0 & 4,2 & 0,30 \\
\hline MASS & Stroke & 5 years & 1,0 & 0,1 & 15,8 & 0,98 \\
\hline MASS II & Stroke & 10 years & 0,6 & 0,3 & 1,4 & 0,23 \\
\hline PRECOMBAT & Stroke & 2 years & 0,5 & 0,0 & 5,5 & 0,57 \\
\hline SYNTAX & Stroke & 5 years & 0,6 & 0,4 & 1,1 & 0,11 \\
\hline \multirow[t]{2}{*}{ Veterans Affairs } & Stroke & 2 years & 1,0 & 0,1 & 15,6 & 0,98 \\
\hline & & & 0,7 & 0,5 & 0,9 & 0,01 \\
\hline
\end{tabular}

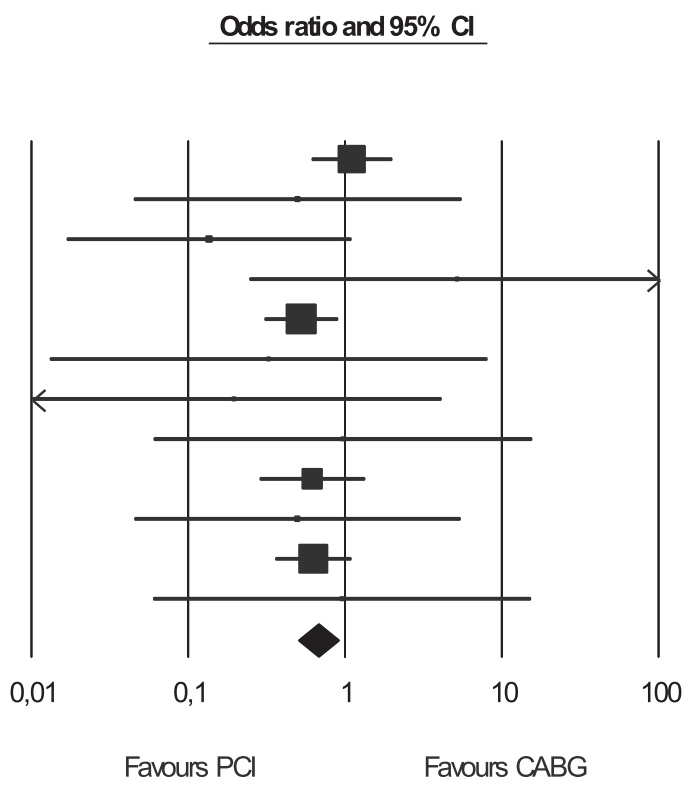

FIGURE E5. Meta-analyzed odds ratios for stroke after PCI or CABG at the latest available follow-up. PCI, Percutaneous coronary intervention; $C A B G$, coronary artery bypass grafting; $C I$, confidence interval; ARTS, Arterial Revascularization Therapies Study; CARDia, Coronary Artery Revascularization in Diabetes; FREEDOM, Future REvascularization Evaluation in patients with Diabetes mellitus: Optimal management of Multivessel disease; MASS, Medicine, Angioplasty, or Surgery Study; PRECOMBAT, Premier of Randomized Comparison of Bypass Surgery versus Angioplasty Using Sirolimus-Eluting Stent in Patients with Left Main Coronary Artery Disease; SYNTAX, Synergy Between Percutaneous Coronary Intervention With Taxus and Cardiac Surgery.

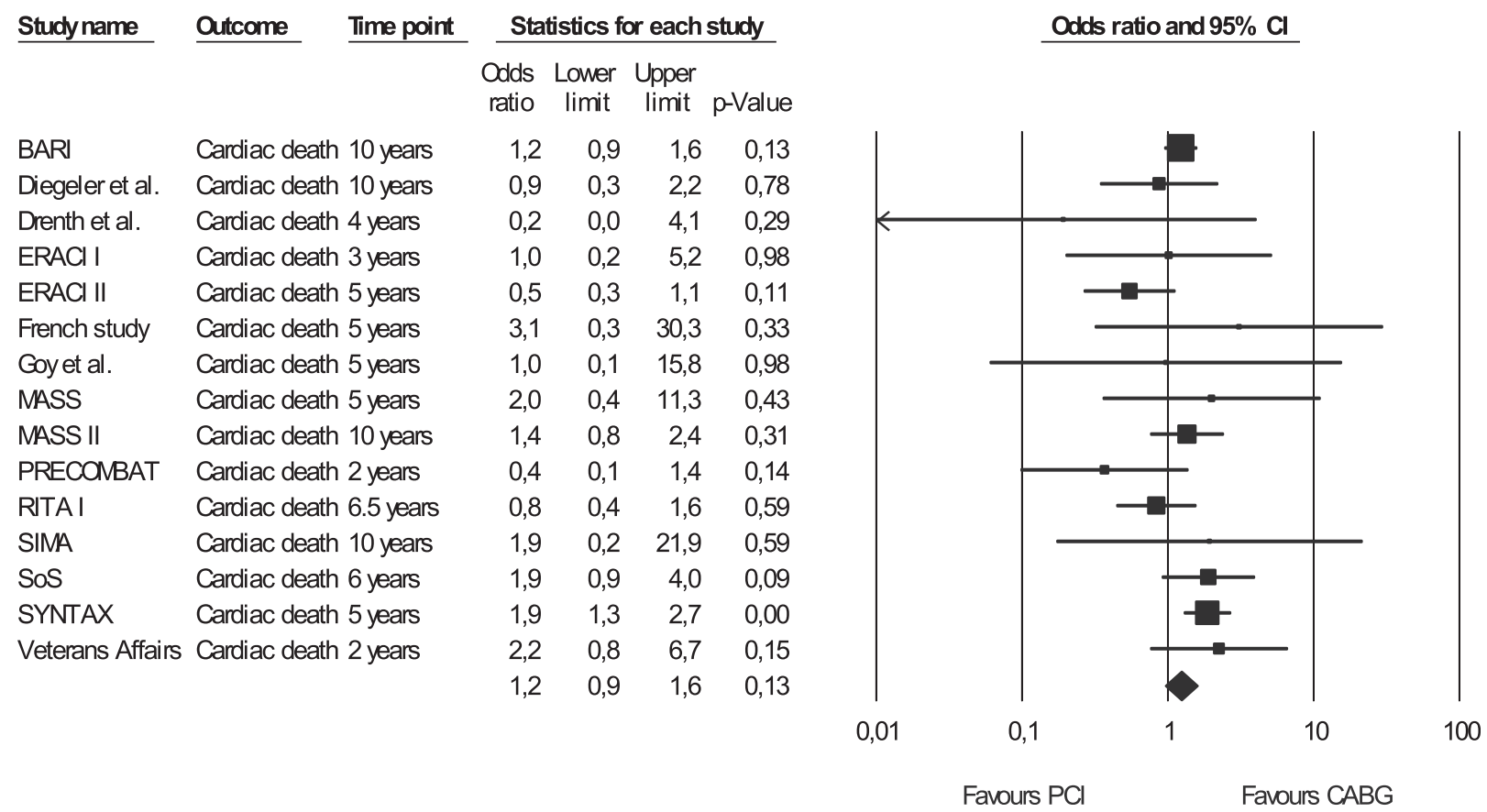

FIGURE E6. Meta-analyzed odds ratios for cardiac death after PCI or CABG at the latest available follow-up. PCI, Percutaneous coronary intervention; $C A B G$, coronary artery bypass grafting; $C I$, confidence interval; BARI, Bypass Angioplasty Revascularization Investigation; ERACI I, Argentine Randomized Trial of Percutaneous Transluminal Coronary Angioplasty Versus Coronary Artery Bypass Surgery in Multivessel Disease; ERACI II, Argentine Randomized Trial of Coronary Angioplasty With Stenting Versus Coronary Bypass Surgery in Patients with Multiple Vessel Disease; MASS, Medicine, Angioplasty, or Surgery Study; PRECOMBAT, Premier of Randomized Comparison of Bypass Surgery versus Angioplasty Using Sirolimus-Eluting Stent in Patients with Left Main Coronary Artery Disease; RITA, Randomised Intervention Treatment of Angina; SIMA, Stenting versus Internal Mammary Artery grafting trial; SoS, Stent or Surgery Trial; SYNTAX, Synergy Between Percutaneous Coronary Intervention With Taxus and Cardiac Surgery. 
Studyname Outcome Time point Statistics for each study

\begin{tabular}{|c|c|c|c|c|c|c|c|c|}
\hline & & & $\begin{array}{l}\text { Odds } \\
\text { ratio }\end{array}$ & $\begin{array}{l}\text { Lower } \\
\text { limit }\end{array}$ & $\begin{array}{c}\text { Upper } \\
\text { limit }\end{array}$ & $p$-Value & & \\
\hline AMIST & AFS & 1.5 years & 1,2 & 0,3 & 4,3 & 0,75 & & \\
\hline ARTS & AFS & 3 years & 0,8 & 0,6 & 1,0 & 0,06 & & \\
\hline CABRI & AFS & 1 year & 0,7 & 0,6 & 0,9 & 0,01 & & \\
\hline Cisonski et al. & AFS & 1 year & 0,0 & 0,0 & 0,7 & 0,03 & F & \\
\hline Diegeler et al. & AFS & 6 months & 0,5 & 0,3 & 0,9 & 0,01 & & \\
\hline Drenth et al. & AFS & 4 years & 0,5 & 0,2 & 1,2 & 0,12 & & \\
\hline ERACI I & AFS & 1 year & 0,4 & 0,2 & 0,8 & 0,01 & & \\
\hline ERACI II & AFS & 5 years & 1,6 & 1,0 & 2,4 & 0,04 & & \\
\hline FREEDOM & AFS & 5 years & 1,1 & 0,7 & 1,8 & 0,71 & & \\
\hline GABI & AFS & 1 year & 0,9 & 0,5 & 1,4 & 0,51 & & \\
\hline Grip et al. & AFS & 6 months & 1,1 & 0,1 & 8,7 & 0,91 & & \\
\hline Kimet al. & AFS & 1 year & 0,3 & 0,1 & 1,0 & 0,05 & & \\
\hline MASS & AFS & 5 years & 0,7 & 0,4 & 1,4 & 0,35 & & \\
\hline MASS II & AFS & 10 years & 0,8 & 0,5 & 1,2 & 0,25 & & \\
\hline Sos & AFS & 1 year & 0,5 & 0,4 & 0,7 & 0,00 & & \\
\hline \multirow[t]{3}{*}{ Thiele } & AFS & 1 year & 1,6 & 0,7 & 3,6 & 0,29 & & \\
\hline & & & 0,7 & 0,6 & 0,9 & 0,01 & & \\
\hline & & & & & & & 0,01 & 0,1 \\
\hline
\end{tabular}

FIGURE E7. Meta-analyzed odds ratios for angina-free survival after PCI or CABG at the latest available follow-up. PCI, Percutaneous coronary intervention; $C A B G$, coronary artery bypass grafting; $A F S$, angina-free survival; $C I$, confidence interval; $A M I S T$, Angioplasty versus Minimally Invasive Surgery Trial; ARTS, Arterial Revascularization Therapies Study; CABRI, Coronary Angioplasty versus Bypass Revascularisation Investigation; ERACII, Argentine Randomized Trial of Percutaneous Transluminal Coronary Angioplasty Versus Coronary Artery Bypass Surgery in Multivessel Disease; ERACI II, Argentine Randomized Trial of Coronary Angioplasty With Stenting Versus Coronary Bypass Surgery in Patients with Multiple Vessel Disease; FREEDOM, Future REvascularization Evaluation in patients with Diabetes mellitus: Optimal management of Multivessel disease; GABI, German Angioplasty Bypass Surgery Investigation; MASS, Medicine, Angioplasty, or Surgery Study; SoS, Stent or Surgery Trial.

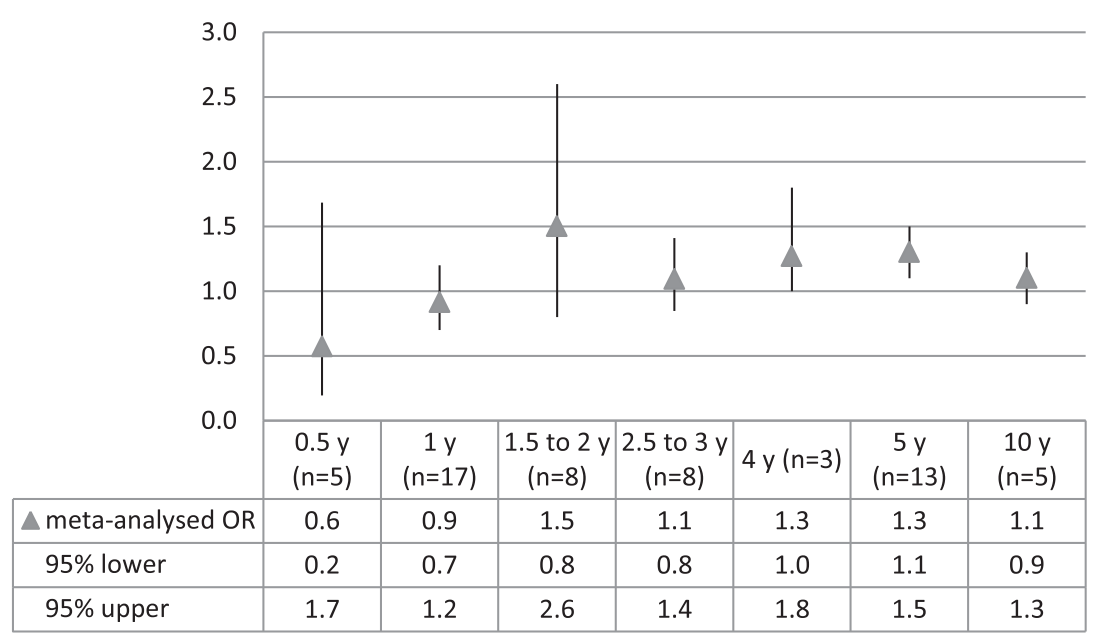

FIGURE E8. Meta-analyzed odds ratios for death per time period of follow-up, PCI versus CABG. OR, Odds ratio; $n$, number of studies meta-analyzed; $y$, years of follow-up. 


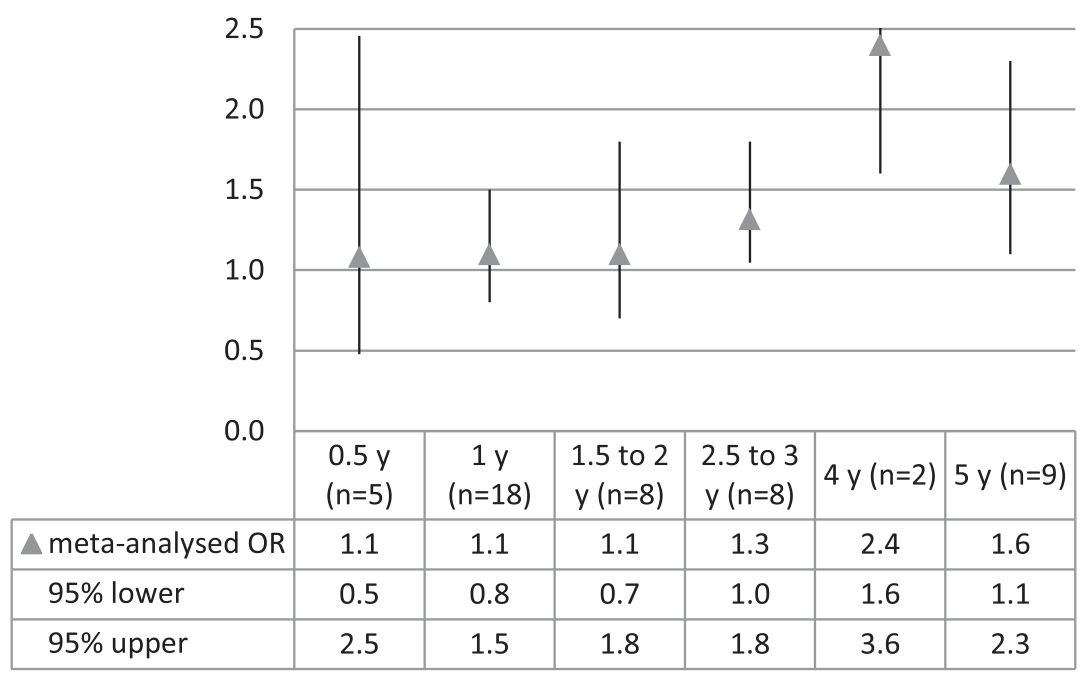

FIGURE E9. Meta-analyzed odds ratios for myocardial infarction per time period of follow-up, PCI versus CABG. OR, Odds ratio; $n$, number of studies meta-analyzed; $y$, years of follow-up.

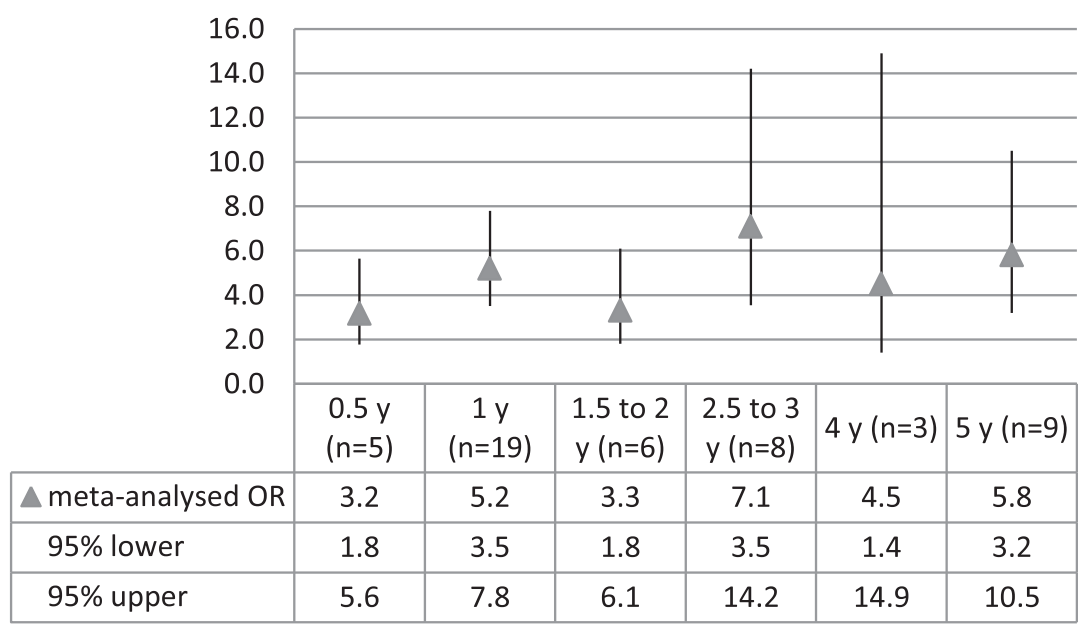

FIGURE E10. Meta-analyzed odds ratios for repeat revascularization per time period of follow-up, PCI versus CABG. OR, Odds ratio; $n$, number of studies meta-analyzed; $y$, years of follow-up. 


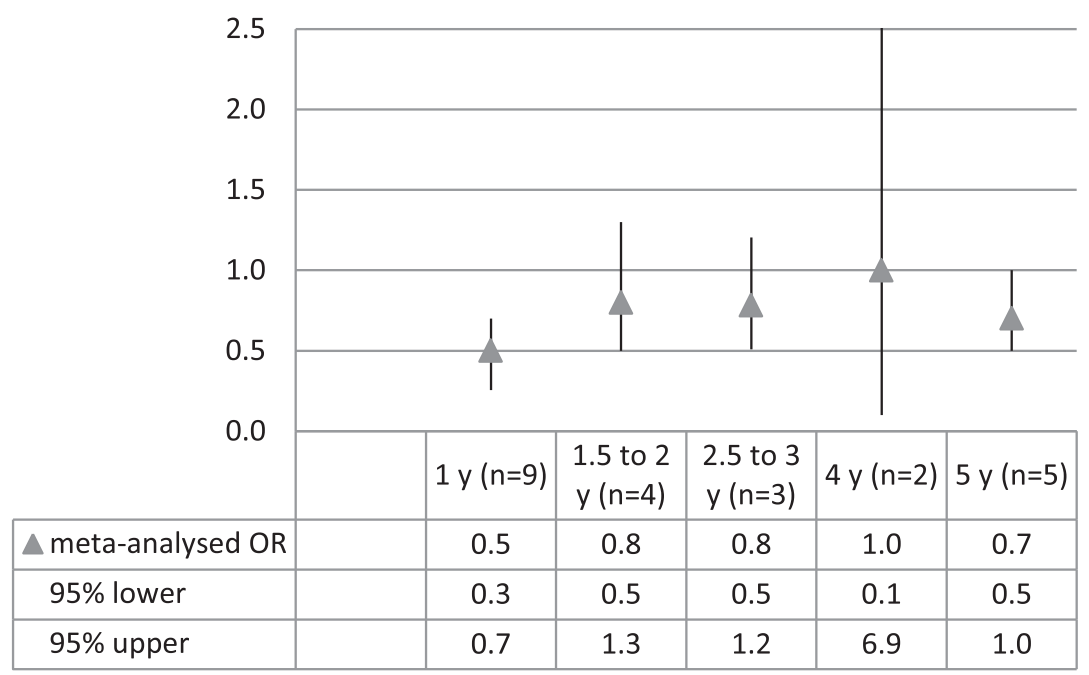

FIGURE E11. Meta-analyzed odds ratios for stroke per time period of follow-up, PCI versus CABG. OR, Odds ratio; $n$, number of studies meta-analyzed; $y$, years of follow-up. 
TABLE E1. Quality assessment of 31 included trials studying PCI versus CABG

\begin{tabular}{|c|c|c|c|c|}
\hline Study & $\begin{array}{c}\text { Adequate } \\
\text { randomization* }\end{array}$ & $\begin{array}{c}\text { Adequate } \\
\text { concealment }\end{array}$ & $\begin{array}{c}\text { Selection } \\
\text { bias } \ddagger\end{array}$ & $\begin{array}{l}\text { Adequate } \\
\text { masking } \S \\
\end{array}$ \\
\hline AMIST & A & A & A & $\mathrm{C}$ \\
\hline ARTS & A & A & A & $\mathrm{C}$ \\
\hline BARI & A & A & A & $\mathrm{C}$ \\
\hline Boudriot & A & A & A & B \\
\hline CABRI & A & A & A & $\mathrm{C}$ \\
\hline CARDia & A & A & A & B \\
\hline Cisowski et al & B & B & A & B \\
\hline Diegeler et al & A & A & A & $\mathrm{C}$ \\
\hline Drenth et al & B & B & A & $\mathrm{C}$ \\
\hline EAST & B & B & A & B \\
\hline ERACI I & B & B & A & $\mathrm{C}$ \\
\hline ERACI II & A & A & A & $\mathrm{C}$ \\
\hline FREEDOM & B & A & B & $\mathrm{C}$ \\
\hline $\begin{array}{l}\text { French } \\
\text { Monocentric } \\
\text { Study }\end{array}$ & B & B & A & $\mathrm{C}$ \\
\hline GABI & B & B & A & $\mathrm{C}$ \\
\hline Goy et al & B & B & A & $\mathrm{C}$ \\
\hline Grip et al & B & B & A & $\mathrm{C}$ \\
\hline Hong et al & B & B & A & $\mathrm{C}$ \\
\hline Kim et al & B & B & A & $\mathrm{C}$ \\
\hline Le Mans & B & B & A & $\mathrm{C}$ \\
\hline MASS I & B & B & A & $\mathrm{C}$ \\
\hline MASS II & B & B & A & $\mathrm{C}$ \\
\hline Myoprotect & B & B & A & $\mathrm{C}$ \\
\hline Octostent & A & A & A & B \\
\hline PRECOMBAT & A & B & A & B \\
\hline RITA & A & A & A & B \\
\hline SIMA & B & B & A & $\mathrm{C}$ \\
\hline SoS & A & A & A & $\mathrm{C}$ \\
\hline SYNTAX & B & A & B & B \\
\hline Thiele & B & B & A & $\mathrm{C}$ \\
\hline Veterans Affairs & B & A & B & B \\
\hline
\end{tabular}

AMIST, Angioplasty versus Minimally Invasive Surgery Trial; ARTS, Arterial Revascularization Therapies Study; BARI, Bypass Angioplasty Revascularization Investigation; CABRI, Coronary Angioplasty versus Bypass Revascularisation Investigation; CARDia, Coronary Artery Revascularization in Diabetes; EAST, Emory Angioplasty versus Surgery Trial; ERACI I, Argentine Randomized Trial of Percutaneous Transluminal Coronary Angioplasty Versus Coronary Artery Bypass Surgery in Multivessel Disease; ERACI II, Argentine Randomized Trial of Coronary Angioplasty With Stenting Versus Coronary Bypass Surgery in Patients with Multiple Vessel Disease; FREEDOM, Future REvascularization Evaluation in patients with Diabetes mellitus: Optimal management of Multivessel disease; GABI, German Angioplasty Bypass Surgery Investigation; MASS, Medicine, Angioplasty, or Surgery Study; PRECOMBAT, Premier of Randomized Comparison of Bypass Surgery versus Angioplasty Using Sirolimus-Eluting Stent in Patients with Left Main Coronary Artery Disease; RITA, Randomised Intervention Treatment of Angina; SIMA, Stenting versus Internal Mammary Artery grafting trial; SoS, Stent or Surgery Trial; SYNTAX, Synergy Between Percutaneous Coronary Intervention With Taxus and Cardiac Surgery. *Adequacy of the randomization process: $A$, adequate sequence generation is reported (such as computer-generated random numbers or random number tables); $B$, did not specify one of the adequate reported methods in (A) but mentioned randomization method; $C$, other methods of allocation that appear to be unbiased; $D$, did not specify one of the adequate reported methods in (A) but mentioned randomization method. $\dagger$ Adequacy of the allocation concealment process: $A$, adequate measures to conceal allocations. Concealment will be deemed adequate where randomization is centralized or pharmacy controlled, or where the following are used: serially numbered containers, on-site computer-based systems where assignment is unreadable until after allocation, other methods with robust methods to prevent foreknowledge of the allocation sequence to clinicians and patients; $B$, unclear concealed trials, in which the authors either did not report allocation concealment approach at all or reported an approach that did not fall into one of the categories in (A); $C$, inadequately concealed trials, in which method of allocation is not concealed. Inadequate approaches will include the use of alternation, case record numbers, days of the week, open random number lists, and serially numbered envelopes, even opaque. $\ddagger$ Potential for selection bias after allocation: $A$, studies where an intention to treat analysis is possible and few exclusions (with adequate reporting of these exclusions); $B$, studies that reported exclusions as reported in (A), but exclusions were less than $10 \% ; C$, no reporting of exclusions; exclusions of $10 \%$ or more or wide differences in exclusions between groups. $\S$ Adequacy of masking: $A$, double (or triple) blind; $B$, single-blind; $C$, nonblind; $D$, unclear. 


\section{E-References}

E1. Bakhai A, Hill RA, Dundar Y, Dickson R, Walley T. Percutaneous transluminal coronary angioplasty with stents versus coronary artery bypass grafting for people with stable angina or acute coronary syndromes. Cochrane Database Syst Rev. 2005;CD004588.

E2. Pocock SJ, Henderson RA, Rickards AF, Hampton JR, King SB III, Hamm CW, et al. Meta-analysis of randomised trials comparing coronary angioplasty with bypass surgery. Lancet. 1995;346:1184-9.

E3. Bravata DM, Gienger AL, McDonald KM, Sundaram V, Perez MV, Varghese R, et al. Systematic review: the comparative effectiveness of percutaneous coronary interventions and coronary artery bypass graft surgery. Ann Intern Med. 2007;147:703-16.

E4. Aziz O, Rao C, Panesar SS, Jones C, Morris S, Darzi A, et al. Meta-analysis of minimally invasive internal thoracic artery bypass versus percutaneous revascularisation for isolated lesions of the left anterior descending artery. BMJ. 2007;334:617.

E5. Jaffery Z, Kowalski M, Weaver WD, Khanal S. A meta-analysis of randomized control trials comparing minimally invasive direct coronary bypass grafting versus percutaneous coronary intervention for stenosis of the proximal left anterior descending artery. Eur J Cardiothorac Surg. 2007;31:691-7.

E6. Boodhwani M, Rubens FD, Sellke FW, Mesana TG, Ruel M. Mortality and myocardial infarction following surgical versus percutaneous revascularization of isolated left anterior descending artery disease: a meta-analysis. Eur J Cardiothorac Surg. 2006;29:65-70.

E7. Rao C, Aziz O, Panesar SS, Jones C, Morris S, Darzi A, et al. Cost effectiveness analysis of minimally invasive internal thoracic artery bypass versus percutaneous revascularisation for isolated lesions of the left anterior descending artery. BMJ. 2007;334:621.

E8. Onuma Y, Daemen J, Kukreja N, Serruys P. Revascularization in the high-risk patient: multivessel disease. Minerva Cardioangiol. 2007;55: 579-92.

E9. Desch S, Boudriot E, Rastan A, Buszman PE, Bochenek A, Mohr FW, et al, Bypass surgery versus percutaneous coronary intervention for the treatment of unprotected left main disease. A meta-analysis of randomized controlled trials. Herz. 2013;38:48-56.

E10. Sipahi I, Akay MH, Dagdelen S, Blitz A, Alhan C. Coronary artery bypass grafting vs percutaneous coronary intervention and long-term mortality and morbidity in multivessel disease: meta-analysis of randomized clinical trials of the arterial grafting and stenting era. JAMA Intern Med. 2014;174: 223-30.

E11. Bainbridge D, Cheng D, Martin J, Novick R. Does off-pump or minimally invasive coronary artery bypass reduce mortality, morbidity, and resource utilization when compared with percutaneous coronary intervention? A meta-analysis of randomized trials. J Thorac Cardiovasc Surg. 2007;133: 623-31.

E12. Hakeem A, Garg N, Bhatti S, Rajpurohit N, Ahmed Z, Uretsky BF. Effectiveness of percutaneous coronary intervention with drug-eluting stents compared with bypass surgery in diabetics with multivessel coronary disease: comprehensive systematic review and meta-analysis of randomized clinical data. J Am Heart Assoc. 2013;2:e000354.

E13. Mercado N, Wijns W, Serruys PW, Sigwart U, Flather MD, Stables RH, et al. One-year outcomes of coronary artery bypass graft surgery versus percutaneous coronary intervention with multiple stenting for multisystem disease: a meta-analysis of individual patient data from randomized clinical trials. $J$ Thorac Cardiovasc Surg. 2005;130:512-9.

E14. Daemen J, Boersma E, Flather M, Booth J, Stables R, Rodriguez A, et al. Long-term safety and efficacy of percutaneous coronary intervention with stenting and coronary artery bypass surgery for multivessel coronary artery disease: a meta-analysis with 5-year patient-level data from the ARTS, ERACI-II, MASS-II, and SoS trials. Circulation. 2008;118:1146-54.

E15. Hlatky MA, Boothroyd DB, Bravata DM, Boersma E, Booth J, Brooks MM, et al. Coronary artery bypass surgery compared with percutaneous coronary interventions for multivessel disease: a collaborative analysis of individual patient data from ten randomised trials. Lancet. 2009;373:1190-7.

E16. Schulz KF, Chalmers I, Hayes RJ, Altman DG. Empirical evidence of bias. Dimensions of methodological quality associated with estimates of treatment effects in controlled trials. JAMA. 1995;273:408-12.

E17. Villanueva EV, Wasiak J, Petherick ES. Percutaneous transluminal rotational atherectomy for coronary artery disease. Cochrane Database Syst Rev. 2003; CD003334.
E18. Ioannidis JP, Patsopoulos NA, Evangelou E. Uncertainty in heterogeneity estimates in meta-analyses. BMJ. 2007;335:914-6.

E19. Higgins JP, Thompson SG. Quantifying heterogeneity in a meta-analysis. Stat Med. 2002;21:1539-58.

E20. Comparison of coronary bypass surgery with angioplasty in patients with multivessel disease. The Bypass Angioplasty Revascularization Investigation (BARI) Investigators. N Engl J Med. 1996;335:217-25.

E21. Five-year clinical and functional outcome comparing bypass surgery and angioplasty in patients with multivessel coronary disease. A multicenter randomized trial. Writing Group for the Bypass Angioplasty Revascularization Investigation (BARI) Investigators. JAMA. 1997;277:715-21.

E22. BARI Investigators. Seven-year outcome in the Bypass Angioplasty Revascularization Investigation (BARI) by treatment and diabetic status. J Am Coll Cardiol. 2000;35:1122-9.

E23. BARI Investigators. The final 10-year follow-up results from the BARI randomized trial. J Am Coll Cardiol. 2007;49:1600-6.

E24. Bourassa MG, Roubin GS, Detre KM, Sopko G, Krone RJ, Attabuto MJ, et al. Bypass Angioplasty Revascularization Investigation: patient screening, selection, and recruitment. Am J Cardiol. 1995;75:3C-8C.

E25. Brooks MM, Jones RH, Bach RG, Chaitman BR, Kern MJ, Orszulak TA, et al. Predictors of mortality and mortality from cardiac causes in the Bypass Angioplasty Revascularization Investigation (BARI) randomized trial and registry. For the BARI Investigators. Circulation. 2000;101:2682-9.

E26. Chaitman BR, Rosen AD, Williams DO, Bourassa MG, Aguirre FV, Pitt B, et al. Myocardial infarction and cardiac mortality in the Bypass Angioplasty Revascularization Investigation (BARI) randomized trial. Circulation. 1997; 96:2162-70.

E27. Mullany CJ, Mock MB, Brooks MM, Kelsey SF, Keller NM, SuttonTyrrell K, et al. Effect of age in the Bypass Angioplasty Revascularization Investigation (BARI) randomized trial. Ann Thorac Surg. 1999;67:396-403.

E28. Influence of diabetes on 5-year mortality and morbidity in a randomized trial comparing $\mathrm{CABG}$ and PTCA in patients with multivessel disease: the Bypass Angioplasty Revascularization Investigation (BARI). Circulation. 1997;96: 1761-9.

E29. Kurbaan AS, Bowker TJ, Rickards AF. Trials of angioplasty and surgery: CABRI. Semin Interv Cardiol. 1999;4:179-84.

E30. First-year results of CABRI (Coronary Angioplasty versus Bypass Revascularisation Investigation). CABRI Trial Participants. Lancet. 1995; 346:1179-84.

E31. Kurbaan AS, Bowker TJ, Ilsley CD, Sigwart U, Rickards AF. Difference in the mortality of the CABRI diabetic and nondiabetic populations and its relation to coronary artery disease and the revascularization mode. Am J Cardiol. 2001;87:947-50.

E32. Kurbaan AS, Bowker TJ, Ilsley CD, Foale RA, Sigwart U, Rickards AF. The effect of adjusting for baseline risk factors and post revascularisation coronary disease on comparisons between coronary angioplasty and bypass surgery. Int J Cardiol. 2001;77:207-14.

E33. King SB III, Kosinski AS, Guyton RA, Lembo NJ, Weintraub WS. Eightyear mortality in the Emory Angioplasty versus Surgery Trial (EAST). $J$ Am Coll Cardiol. 2000;35:1116-21.

E34. King SB III, Barnhart HX, Kosinski AS, Weintraub WS, Lembo NJ, Petersen JY, et al. Angioplasty or surgery for multivessel coronary artery disease: comparison of eligible registry and randomized patients in the EAST trial and influence of treatment selection on outcomes. Emory Angioplasty versus Surgery Trial Investigators. Am J Cardiol. 1997;79:1453-9.

E35. King SB III, Lembo NJ, Weintraub WS, Kosinski AS, Barnhart HX, Kutner $\mathrm{MH}$, et al. A randomized trial comparing coronary angioplasty with coronary bypass surgery. Emory Angioplasty versus Surgery Trial (EAST). N Engl J Med. 1994;331:1044-50.

E36. King SB III. The Emory Angioplasty vs Surgery Trial (EAST). Semin Interv Cardiol. 1999; 4:185-90.

E37. Rodriguez A, Boullon F, Perez-Balino N, Paviotti C, Liprandi MI, Palacios IF. Argentine Randomized Trial of Percutaneous Transluminal Coronary Angioplasty Versus Coronary Artery Bypass Surgery in Multivessel Disease (ERACI): in-hospital results and 1-year follow-up. ERACI Group. J Am Coll Cardiol. 1993;22:1060-7.

E38. Rodriguez A, Mele E, Peyregne E, Bullon F, Perez-Balino N, Liprandi MI, et al. Three-year follow-up of the Argentine Randomized Trial of Percutaneous Transluminal Coronary Angioplasty Versus Coronary Artery Bypass Surgery in Multivessel Disease (ERACI). J Am Coll Cardiol. 1996;27: $1178-84$. 
E39. Carrie D, Elbaz M, Puel J, Fourcade J, Karouny E, Fournial G, et al. Five-year outcome after coronary angioplasty versus bypass surgery in multivessel coronary artery disease: results from the French Monocentric Study. Circulation. 1997;96(9 Suppl):II-1-6.

E40. Kaehler J, Koester R, Billmann W, Schroeder C, Rupprecht HJ, Ischinger T, et al. 13-year follow-up of the German Angioplasty Bypass Surgery Investigation. Eur Heart J. 2005;26:2148-53.

E41. Hamm CW, Reimers J, Ischinger T, Rupprecht HJ, Berger J, Bleifeld W. A randomized study of coronary angioplasty compared with bypass surgery in patients with symptomatic multivessel coronary disease. German Angioplasty Bypass Surgery Investigation (GABI). N Engl J Med. 1994;331:1037-43.

E42. Goy JJ, Eeckhout E, Moret C, Burnand B, Vogt P, Stauffer JC, et al. Five-year outcome in patients with isolated proximal left anterior descending coronary artery stenosis treated by angioplasty or left internal mammary artery grafting. A prospective trial. Circulation. 1999;99:3255-9.

E43. Goy JJ, Eeckhout E, Burnand B, Vogt P, Stauffer JC, Hurni M, et al. Coronary angioplasty versus left internal mammary artery grafting for isolated proximal left anterior descending artery stenosis. Lancet. 1994; $343: 1449-53$.

E44. Hueb WA, Soares PR, meida De OS, Arie S, Cardoso RH, Wajsbrot DB, et al. Five-year follow-op of the medicine, angioplasty, or surgery study (MASS): a prospective, randomized trial of medical therapy, balloon angioplasty, or bypass surgery for single proximal left anterior descending coronary artery stenosis. Circulation. 1999;100(19 Suppl):II107-13.

E45. Hueb WA, Bellotti G, de Oliveira SA, Arie S, de Albuquerque CP, Jatene AD, et al. The Medicine, Angioplasty or Surgery Study (MASS): a prospective, randomized trial of medical therapy, balloon angioplasty or bypass surgery for single proximal left anterior descending artery stenoses. J Am Coll Cardiol. 1995;26:1600-5.

E46. Hampton JR. Long-term results of RITA-1. Eur Heart J. 1999;20:849-50.

E47. Hampton JR. RITA. Semin Interv Cardiol. 1999;4:169-77.

E48. Henderson RA. The Randomised Intervention Treatment of Angina (RITA) Trial protocol: a long term study of coronary angioplasty and coronary artery bypass surgery in patients with angina. Br Heart J. 1989;62:411-4.

E49. Henderson RA, Pocock SJ, Sharp SJ, Nanchahal K, Sculpher MJ, Buxton MJ, et al. Long-term results of RITA-1 trial: clinical and cost comparisons of coronary angioplasty and coronary-artery bypass grafting. Randomised Intervention Treatment of Angina. Lancet. 1998;352:1419-25.

E50. Pocock SJ, Henderson RA, Seed P, Treasure T, Hampton JR. Quality of life, employment status, and anginal symptoms after coronary angioplasty or bypass surgery. 3-year follow-up in the Randomized Intervention Treatment of Angina (RITA) Trial. Circulation. 1996;94:135-42.

E51. Reeves BC, Angelini GD, Bryan AJ, Taylor FC, Cripps T, Spyt TJ, et al. A multi-centre randomised controlled trial of minimally invasive direct coronary bypass grafting versus percutaneous transluminal coronary angioplasty with stenting for proximal stenosis of the left anterior descending coronary artery. Health Technol Assess. 2004;8:1-43.

E52. Legrand VM, Serruys PW, Unger F, van Hout BA, Vrolix MC, Fransen GM, et al. Three-year outcome after coronary stenting versus bypass surgery for the treatment of multivessel disease. Circulation. 2004;109:1114-20.

E53. Unger F, Serruys PW, Yacoub MH, Ilsley C, Paulsen PK, Nielsen TT, et al. Revascularization in multivessel disease: comparison between two-year outcomes of coronary bypass surgery and stenting. J Thorac Cardiovasc Surg. 2003;125:809-20.

E54. Serruys PW, Ong AT, van Herwerden LA, Sousa JE, Jatene A, Bonnier JJ, et al. Five-year outcomes after coronary stenting versus bypass surgery for the treatment of multivessel disease: the final analysis of the Arterial Revascularization Therapies Study (ARTS) randomized trial. J Am Coll Cardiol. 2005;46:575-81.

E55. Serruys PW, Unger F, van Hout BA, van den Brand MJ, van Herwerden LA, van Es GA, et al. The ARTS study (Arterial Revascularization Therapies Study). Semin Interv Cardiol. 1999;4:209-19.

E56. Serruys PW, Unger F, Sousa JE, Jatene A, Bonnier HJ, Schonberger JP, et al. Comparison of coronary-artery bypass surgery and stenting for the treatment of multivessel disease. N Engl J Med. 2001;344:1117-24.

E57. Aoki J, Ong AT, Arampatzis CA, Vijaykumar M, Rodriguez Granillo GA, Disco CM, et al. Comparison of three-year outcomes after coronary stenting versus coronary artery bypass grafting in patients with multivessel coronary disease, including involvement of the left anterior descending coronary artery proximally (a subanalysis of the arterial revascularization therapies study trial). Am J Cardiol. 2004:94:627-31.
E58. de Feyter PJ, Serruys PW, Unger F, Beyar R, de Valk V, Milo S, et al. Bypass surgery versus stenting for the treatment of multivessel disease in patients with unstable angina compared with stable angina. Circulation. 2002;105:2367-72.

E59. Abizaid A, Costa MA, Centemero M, Abizaid AS, Legrand VM, Limet RV, et al. Clinical and economic impact of diabetes mellitus on percutaneous and surgical treatment of multivessel coronary disease patients: insights from the Arterial Revascularization Therapy Study (ARTS) trial. Circulation. 2001;104:533-8.

E60. Cisowski M, Drzewiecki J, Drzewiecka-Gerber A, Jaklik A, Kruczak W, Szczeklik M, et al. Primary stenting versus MIDCAB: preliminary reportcomparision of two methods of revascularization in single left anterior descending coronary artery stenosis. Ann Thorac Surg. 2002;74:S1334-9.

E61. Cisowski M, Drzewiecka-Gerber A, Ulczok R, Abu SR, Drzewiecki J, Guzy M, et al. Primary direct stenting versus endoscopic atraumatic coronary artery bypass surgery in patients with proximal stenosis of the left anterior descending coronary artery — a prospective, randomised study. Kardiol Pol. 2004;61:253-61.

E62. Diegeler A, Thiele H, Falk V, Hambrecht R, Spyrantis N, Sick P, et al Comparison of stenting with minimally invasive bypass surgery for stenosis of the left anterior descending coronary artery. N Engl J Med. 2002;347:561-6.

E63. Blazek S, Holzhey D, Jungert C, Borger MA, Fuernau G, Desch S, et al. Comparison of bare-metal stenting with minimally invasive bypass surgery for stenosis of the left anterior descending coronary artery: 10-year follow-up of a randomized trial. JACC Cardiovasc Interv. 2013;6:20-6.

E64. Thiele H, Oettel S, Jacobs S, Hambrecht R, Sick P, Gummert JF, et al Comparison of bare-metal stenting with minimally invasive bypass surgery for stenosis of the left anterior descending coronary artery: a 5-year follow-up. Circulation. 2005;112:3445-50.

E65. Drenth DJ, Veeger NJ, Grandjean JG, Mariani MA, van Boven AJ, Boonstra PW. Isolated high-grade lesion of the proximal LAD: a stent or off-pump LIMA? Eur J Cardiothorac Surg. 2004;25:567-71.

E66. Drenth DJ, Veeger NJ, Winter JB, Grandjean JG, Mariani MA, Boven van AJ et al. A prospective randomized trial comparing stenting with off-pump coronary surgery for high-grade stenosis in the proximal left anterior descending coronary artery: three-year follow-up. J Am Coll Cardiol. 2002; 40:1955-60.

E67. Drenth DJ, Winter JB, Veeger NJ, Monnink SH, van Boven AJ, Grandjean JG, et al. Minimally invasive coronary artery bypass grafting versus percutaneous transluminal coronary angioplasty with stenting in isolated high-grade stenosis of the proximal left anterior descending coronary artery: six months' angiographic and clinical follow-up of a prospective randomized study. J Thorac Cardiovasc Surg. 2002;124:130-5.

E68. Drenth DJ, Veeger NJ, Middel B, Zijlstra F, Boonstra PW. Comparison of late (four years) functional health status between percutaneous transluminal angioplasty intervention and off-pump left internal mammary artery bypass grafting for isolated high-grade narrowing of the proximal left anterio descending coronary artery. Am J Cardiol. 2004;94:1414-7.

E69. Rodriguez A, Bernardi V, Navia J, Baldi J, Grinfeld L, Martinez J, et al Argentine Randomized Study: Coronary Angioplasty With Stenting versus Coronary Bypass Surgery in Patients With Multiple-Vessel Disease (ERACI II): 30-day and one-year follow-up results. ERACI II Investigators. J Am Coll Cardiol. 2001;37:51-8.

E70. Rodriguez AE, Baldi J, Fernandez PC, Navia J, Rodriguez AM, Delacasa A, et al. Five-year follow-up of the Argentine Randomized Trial of Coronary Angioplasty With Stenting Versus Coronary Bypass Surgery in Patients With Multiple Vessel Disease (ERACI II). J Am Coll Cardiol. 2005;46:582-8.

E71. Grip L, Wahrborg P, Odell A, Albertsson P, Berglin P, Brandrup-Wognsen G et al. Coronary artery bypass beating heart surgery with LIMA graft, versus coronary angioplasty with stent for patients with single left anterior descending artery—a pilot study. Eur Heart J. 2001;22(Suppl):597.

E72. Kim JW, Lim DS, Sun K, Shim WJ, Rho YM. Stenting or MIDCAB using ministernotomy for revascularization of proximal left anterior descending artery? Int J Cardiol. 2005;99:437-41.

E73. Buszman PE, Kiesz SR, Bochenek A, Peszek-Przybyla E, Szkrobka I, Debinski M, et al. Acute and late outcomes of unprotected left main stenting in comparison with surgical revascularization. J Am Coll Cardiol. 2008;51: 538-45.

E74. Pawel BE, Buszman PP. Late outcomes of unprotected left main stenting in comparison with surgical revascularization - ten-year clinical follow up of the LEMANS trial. J Am Coll Cardiol. 2013;62:B9.

E75. Hueb W, Lopes NH, Gersh BJ, Soares P, Machado LA, Jatene FB, et al Five-year follow-up of the Medicine, Angioplasty, or Surgery Study (MASS II): a randomized controlled clinical trial of 3 therapeutic 
strategies for multivessel coronary artery disease. Circulation. 2007;115: 1082-9.

E76. Hueb W, Soares PR, Gersh BJ, Cesar LA, Luz PL, Puig LB, et al. The medicine, angioplasty, or surgery study (MASS-II): a randomized, controlled clinical trial of three therapeutic strategies for multivessel coronary artery disease: one-year results. J Am Coll Cardiol. 2004;43:1743-51.

E77. Soares PR, Hueb WA, Lemos PA, Lopes N, Martinez EE, Cesar LA, et al. Coronary revascularization (surgical or percutaneous) decreases mortality after the first year in diabetic subjects but not in nondiabetic subjects with multivessel disease: an analysis from the Medicine, Angioplasty, or Surgery Study (MASS II). Circulation. 2006;114(1 Suppl):I420-4.

E78. Favarato ME, Hueb W, Boden WE, Lopes N, Nogueira CR, Takiuti M, et al. Quality of life in patients with symptomatic multivessel coronary artery disease: a comparative post hoc analyses of medical, angioplasty or surgical strategies-MASS II trial. Int J Cardiol. 2007;116:364-70.

E79. Hueb W, Lopes N, Gersh BJ, Soares PR, Ribeiro EE, Pereira AC, et al. Tenyear follow-up survival of the Medicine, Angioplasty, or Surgery Study (MASS II): a randomized controlled clinical trial of 3 therapeutic strategies for multivessel coronary artery disease. Circulation. 2010;122:949-57.

E80. Lima EG, Hueb W, Garcia RM, Pereira AC, Soares PR, Favarato D, et al. Impact of diabetes on 10-year outcomes of patients with multivessel coronary artery disease in the Medicine, Angioplasty, or Surgery Study II (MASS II) trial. Am Heart J. 2013;166:250-7.

E81. Pohl T, Giehrl W, Reichart B, Kupatt C, Raake P, Paul S, et al. Retroinfusion-supported stenting in high-risk patients for percutaneous intervention and bypass surgery: results of the prospective randomized myoprotect I study. Catheter Cardiovasc Interv. 2004;62:323-30.

E82. Nathoe HM, Van Dijk D, Jansen EWL, Borst C, Grobbee DE, De Jaegere PPT, et al. Off-pump coronary artery bypass surgery compared with stent implantation and on-pump bypass surgery: clinical outcome and cost-effectiveness at one year. Neth Heart J. 2005;13:213-22.

E83. Eefting F, Nathoe H, van DD, Jansen E, Lahpor J, Stella P, et al. Randomized comparison between stenting and off-pump bypass surgery in patients referred for angioplasty. Circulation. 2003;108:2870-6.

E84. Nathoe HM, Regieli JJ, Van Dijk D, Stella PR, Lahpor JR, Buijsrogge MP. Long-term clinical and angiographic outcome after stent-implantation versus off-pump coronary bypass surgery. Eur Heart J. 2011;32.

E85. Goy JJ, Kaufmann U, Goy-Eggenberger D, Garachemani A, Hurni M, Carrel T, et al. A prospective randomized trial comparing stenting to internal mammary artery grafting for proximal, isolated de novo left anterior coronary artery stenosis: the SIMA trial. Stenting vs Internal Mammary Artery. Mayo Clin Proc. 2000;75:1116-23.

E86. Goy JJ, Kaufmann U, Hurni M, Cook S, Versaci F, Ruchat P, et al. 10-year follow-up of a prospective randomized trial comparing bare-metal stenting with internal mammary artery grafting for proximal, isolated de novo left anterior coronary artery stenosis the SIMA (Stenting versus Internal Mammary Artery grafting) trial. J Am Coll Cardiol. 2008;52:815-7.

E87. SoS Investigators. Coronary artery bypass surgery versus percutaneous coronary intervention with stent implantation in patients with multivessel coronary artery disease (the Stent or Surgery trial): a randomised controlled trial. Lancet. 2002;360:965-70.

E88. Zhang Z, Mahoney EM, Stables RH, Booth J, Nugara F, Spertus JA, et al. Disease-specific health status after stent-assisted percutaneous coronary intervention and coronary artery bypass surgery: one-year results from the Stent or Surgery trial. Circulation. 2003;108:1694-700.

E89. Zhang Z, Mahoney EM, Spertus JA, Booth J, Nugara F, Kolm P, et al. The impact of age on outcomes after coronary artery bypass surgery versus stent-assisted percutaneous coronary intervention: one-year results from the Stent or Surgery (SoS) trial. Am Heart J. 2006;152:1153-60.

E90. Booth J, Clayton T, Pepper J, Nugara F, Flather M, Sigwart U, et al. Randomized, controlled trial of coronary artery bypass surgery versus percutaneous coronary intervention in patients with multivessel coronary artery disease: six-year follow-up from the Stent or Surgery Trial (SoS). Circulation. 2008;118:381-8.

E91. Boudriot E, Thiele H, Walther T, Liebetrau C, Boeckstegers P, Pohl T, et al. Randomized comparison of percutaneous coronary intervention with sirolimus-eluting stents versus coronary artery bypass grafting in unprotected left main stem stenosis. J Am Coll Cardiol. 2011;57:538-45.

E92. Boudriot E, Thiele H, Neumann FJ, Gick M, Reichard B, Boekstegers P, et al. 5-year results of treatment of Unprotected Left Main Stenosis by CABG or
PCI with Sirolimus eluting stent. A multicenter, randomized trial. J Am Coll Cardiol. 2011;58(20 Suppl B):B89.

E93. Kapur A, Hall RJ, Malik IS, Qureshi AC, Butts J, de BM, et al. Randomized comparison of percutaneous coronary intervention with coronary artery bypass grafting in diabetic patients. 1-year results of the CARDia (Coronary Artery Revascularization in Diabetes) trial. J Am Coll Cardiol. 2010;55:432-40.

E94. Farkouh ME, Domanski M, Sleeper LA, Siami FS, Dangas G, Mack M, et al. Strategies for multivessel revascularization in patients with diabetes. $N$ Engl J Med. 2012;367:2375-84.

E95. Farkouh ME, Dangas G, Leon MB, Smith C, Nesto R, Buse JB, et al. Design of the Future REvascularization Evaluation in patients with Diabetes mellitus: Optimal management of Multivessel disease (FREEDOM) Trial. Am Heart J. 2008;155:215-23.

E96. Abdallah MS, Wang K, Magnuson EA, Spertus JA, Farkouh ME, Fuster V, et al. Quality of life after PCI vs CABG among patients with diabetes and multivessel coronary artery disease: a randomized clinical trial. JAMA. 2013;310:1581-90.

E97. Hong SJ, Lim DS, Seo HS, Kim YH, Shim WJ, Park CG, et al. Percutaneous coronary intervention with drug-eluting stent implantation vs. minimally invasive direct coronary artery bypass (MIDCAB) in patients with left anterior descending coronary artery stenosis. Catheter Cardiovasc Interv. 2005;64: $75-81$.

E98. Park SJ, Kim YH, Park DW, Yun SC, Ahn JM, Song HG, et al. Randomized trial of stents versus bypass surgery for left main coronary artery disease. $N$ Engl J Med. 2011;364:1718-27.

E99. Serruys PW, Morice MC, Kappetein AP, Colombo A, Holmes DR, Mack MJ, et al. Percutaneous coronary intervention versus coronary-artery bypass grafting for severe coronary artery disease. N Engl J Med. 2009;360:961-72.

E100. Kappetein AP, Feldman TE, Mack MJ, Morice MC, Holmes DR, Stahle E, et al. Comparison of coronary bypass surgery with drug-eluting stenting for the treatment of left main and/or three-vessel disease: 3-year follow-up of the SYNTAX trial. Eur Heart J. 2011;32:2125-34.

E101. Mack MJ, Banning AP, Serruys PW, Morice MC, Taeymans Y, Van NG, et al. Bypass versus drug-eluting stents at three years in SYNTAX patients with diabetes mellitus or metabolic syndrome. Ann Thorac Surg. 2011;92:2140-6.

E102. Banning AP, Westaby S, Morice MC, Kappetein AP, Mohr FW, Berti S, et al. Diabetic and nondiabetic patients with left main and/or 3-vessel coronary artery disease: comparison of outcomes with cardiac surgery and paclitaxeleluting stents. J Am Coll Cardiol. 2010;55:1067-75.

E103. Mohr FW, Morice MC, Kappetein AP, Feldman TE, Stahle E, Mack MJ, et al. Final five-year follow-up of the SYNTAX trial: optimal revascularisation strategy in patients with three-vessel disease and/or left main disease. Eur Heart J. 2012;33:500

E104. Kappetein AP, Head SJ, Morice M, Banning A, Serruys P, Mohr F, et al. Treatment of complex coronary artery disease in patients with diabetes: 5-year results comparing outcomes of coronary artery bypass grafting and percutaneous coronary intervention in the syntax study. Interact Cardiovasc Thorac Surg. 2012;15:S74.

E105. Kappetein AP, Head SJ, Morice MC, Banning AP, Serruys PW, Mohr FW, et al. Treatment of complex coronary artery disease in patients with diabetes: 5-year results comparing outcomes of bypass surgery and percutaneous coronary intervention in the SYNTAX trial. Eur J Cardiothorac Surg. 2013;43:1006-13.

E106. Mack MJ, Head SJ, Holmes DR Jr, Stahle E, Feldman TE, Colombo A, et al. Analysis of stroke occurring in the SYNTAX trial comparing coronary artery bypass surgery and percutaneous coronary intervention in the treatment of complex coronary artery disease. JACC Cardiovasc Interv. 2013;6:344-54.

E107. Farooq V, Serruys PW, Bourantas C, Vranckx P, Diletti R, Garcia Garcia HM, et al. Incidence and multivariable correlates of long-term mortality in patients treated with surgical or percutaneous revascularization in the synergy between percutaneous coronary intervention with taxus and cardiac surgery (SYNTAX) trial. Eur Heart J. 2012;33:3105-13.

E108. Mohr FW, Morice MC, Kappetein AP, Feldman TE, Stahle E, Colombo A, et al. Coronary artery bypass graft surgery versus percutaneous coronary intervention in patients with three-vessel disease and left main coronary disease: 5-year follow-up of the randomised, clinical SYNTAX trial. Lancet. 2013;381:629-38

E109. Thiele H, Neumann-Schniedewind P, Jacobs S, Boudriot E, Walther T, Mohr FW, et al. Randomized comparison of minimally invasive direct coronary artery bypass surgery versus sirolimus-eluting stenting in isolated 
proximal left anterior descending coronary artery stenosis. J Am Coll Cardiol. 2009;53:2324-31.

E110. Kamalesh M, Sharp TG, Tang XC, Shunk K, Ward HB, Walsh J, et al. Percutaneous coronary intervention versus coronary bypass surgery in United States veterans with diabetes. J Am Coll Cardiol. 2013;61: 808-16.

E111. Morrison DA, Sethi G, Sacks J, Henderson W, Grover F, Sedlis S, et al. Percutaneous coronary intervention versus coronary artery bypass graft surgery for patients with medically refractory myocardial ischemia and risk factors for adverse outcomes with bypass: a multicenter, randomized trial. Investigators of the Department of Veterans Affairs Cooperative Study \#385, the Angina With Extremely Serious Operative Mortality Evaluation (AWESOME). J Am Coll Cardiol. 2001;38:143-9.

E112. Morrison DA, Sethi G, Sacks J, Grover F, Sedlis S, Esposito R, et al. A multicenter, randomized trial of percutaneous coronary intervention versus bypass surgery in high-risk unstable angina patients. The AWESOME (Veterans Affairs Cooperative Study \#385, angina with extremely serious operative mortality evaluation) investigators from the Cooperative Studies Program of the Department of Veterans Affairs. Control Clin Trials. 1999; 20:601-19.

E113. Stroupe KT, Morrison DA, Hlatky MA, Barnett PG, Cao L, Lyttle C, et al. Cost-effectiveness of coronary artery bypass grafts versus percutaneous coronary intervention for revascularization of high-risk patients. Circulation. 2006;114:1251-7.

E114. Ramanathan KB, Weiman DS, Sacks J, Morrison DA, Sedlis S, Sethi G, et al. Percutaneous intervention versus coronary bypass surgery for patients older than 70 years of age with high-risk unstable angina. Ann Thorac Surg. 2005;80:1340-6.

E115. Rumsfeld JS, Magid DJ, Plomondon ME, Sacks J, Henderson W, Hlatky M, et al. Health-related quality of life after percutaneous coronary intervention versus coronary bypass surgery in high-risk patients with medically refractory ischemia. J Am Coll Cardiol. 2003;41:1732-8.

E116. Sedlis SP, Morrison DA, Lorin JD, Esposito R, Sethi G, Sacks J, et al Percutaneous coronary intervention versus coronary bypass graft surgery for diabetic patients with unstable angina and risk factors for adverse outcomes with bypass: outcome of diabetic patients in the AWESOME randomized trial and registry. J Am Coll Cardiol. 2002;40:1555-66.

E117. Sedlis SP, Ramanathan KB, Morrison DA, Sethi G, Sacks J, Henderson W Outcome of percutaneous coronary intervention versus coronary bypass grafting for patients with low left ventricular ejection fractions, unstable angina pectoris, and risk factors for adverse outcomes with bypass (the AWESOME Randomized Trial and Registry). Am J Cardiol. 2004;94:118-20.

E118. Capodanno D, Tamburino C. Unraveling the EXCEL: promises and chal lenges of the next trial of left main percutaneous coronary intervention. Int J Cardiol. 2012;156:1-3.

E119. Tong BC, Huber JC, Ascheim DD, Puskas JD, Ferguson TB Jr, Blackstone EH, et al. Weighting composite endpoints in clinical trials: essential evidence for the heart team. Ann Thorac Surg. 2012;94:1908-13.

E120. Palmerini T, Biondi-Zoccai G, Riva DD, Mariani A, Savini C, Di EM, et al. Risk of stroke with percutaneous coronary intervention compared with on-pump and off-pump coronary artery bypass graft surgery: evidence from a comprehensive network meta-analysis. Am Heart J. 2013;165:910-7. 